\title{
Pengaruh Kemahiran Generik dalam Kemahiran Pemikiran Kritikal, Penyelesaian Masalah dan Komunikasi Pelajar Universiti Kebangsaan Malaysia (UKM)
}

\author{
RODIAH IDRIS \\ SITI RAHAYAH ARIFFIN \\ NORIAH MOHD ISHAK \\ Universiti Kebangsaan Malaysia
}

\begin{abstract}
ABSTRAK
Kemahiran generik adalah kemahiran yang diperlukan oleh pelajar selain akademik untuk menjadi lebih berjaya dan cemerlang sebagai pengamal dalam bidang akademik, pekerjaan, dan kehidupan. Kemahiran generik diintegrasikan dalam pengajaran dan pembelajaran dalam konteks subjek pengajian dan merupakan kemahiran boleh pindah atau transferable skills. Penilaian kemahiran generik di Institusi Pengajian Tinggi (IPT) mula diberi fokus apabila Malaysian Qualification Framework (MQF) di laksanakan pada tahun 2006. Tujuan kajian ini adalah untuk mengenal pasti pengaruh atau petunjuk utama kemahiran generik terhadap kemahiran berfikiran kritikal, penyelesaian masalah dan komunikasi pelajar. Kajian ini menggunakan Instrumen Kemahiran Generik Pengajian Tinggi (GeSIHE) yang dibina oleh sekumpulan penyelidik Universiti Kebangsaan Malaysia (UKM). Instrumen GeSIHE mengandungi 13 konstruk dengan 102 item dan ditadbirkan kepada 1,262 orang pelajar prasiswazah di 12 fakulti UKM yang dipilih secara rawak berkelompok. Kebolehpercayaan GeSIHE adalah tinggi iaitu dari 0.98 hingga 0.99. Analisis multi-regresi stepwise menunjukkan secara signifikan kemahiran kepimpinan dalam aspek menghasilkan idea dan sering berinteraksi pada masa yang singkat adalah petunjuk utama menyebabkan pelajar UKM mahir dalam berkomunikasi. Manakala kemahiran pembelajaran sepanjang hayat atau keupayaan pembelajaran sepanjang masa merupakan petunjuk utama yang menyebabkan pelajar universiti mahir dalam kemahiran pemikiran kritikal dan menyelesaikan masalah.
\end{abstract}




\section{ABSTRACT}

Purpose - The purpose of this study was to identify the contribution of generic skills on communication, critical thinking, and problem solving skills.

Method - This study used the Generic Skills Instrument for Higher Education (GeSIHE) developed by a group of researchers from Universiti Kebangsaan Malaysia (UKM). The GeSIHE instrument contains 13 constructs with 102 items, and was administered to 1,262 students in 12 faculties at UKM. The samples were clustered and randomly chosen.

Findings - The reliability construct of GeSIHE was high i.e. 0.98 to 0.99 . The multi-regression stepwise analysis showed that leadership skills or the capacity to lead and frequent brief interactions with others is the significant key index that shows a university student's skill in communication. On the other hand, lifelong learning or life time learning potential and ability to generate ideas is the key index which shows that a university student is skilled in critical thinking and problem solving.

Value - This study will render guidance to students, teaching staff, university and stakeholders of the importance of moulding generic skills in teaching and learning.

Keywords - Generic skills, Generic skill instrument for Higher Education (GeSIHE), Critical thinking skill and problem solving, Communication skill, Multi-regression stepwise analysis

\section{PENGENALAN}

Di Malaysia penilaian kemahiran generik pelajar di Institusi Pengajian Tinggi (IPT) mulai diberi fokus (Sharifah Hapsah, 2006) apabila terlaksana Malaysian Qualification Framework (MQF) pada tahun 2006. Pembinaan instrumen kemahiran generik GeSIHE 2008 ini adalah berdasarkan MQF 2006 yang berlandaskan teori kognitif, behaviorisme dan sosial. Pada peringkat bidang dan program MQF menekankan lapan domain hasil pembelajaran yang dianggap penting bagi Malaysia iaitu: (1) pengetahuan ilmu bidang, (2) kemahiran praktikal, (3) kemahiran dan kebertanggungjawaban 
sosial, (4) etika, moral dan keprofesionalisme, (5) kemahiran komunikasi, kepimpinan dan kerja berpasukan, (6) kemahiran pemikiran kritikal, penyelesaian masalah dan kemahiran saintifik, (7) pengurusan maklumat dan kemahiran pembelajaran sepanjang hayat, dan (8) kemahiran mengurus dan keusahawanan (Sharifah Hapsah, 2006).

Kemahiran generik ialah kemahiran yang diperlukan oleh pelajar selain bidang akademik untuk menjadi lebih berjaya dan cemerlang sebagai pengamal dalam bidang akademik, pekerjaan dan kehidupan (Falk \& Millar 2002; Hambur, Rowe \& Luc, 2002; Lublin, 2003). Kemahiran generik diterapkan atau diintegrasikan dalam pengajaran dan pembelajaran dalam konteks subjek pengajian dan merupakan kemahiran boleh pindah - transferable skills (Kearns, 2001). Proses penilaian dan jaminan kualiti setiap graduan yang dilahirkan merupakan salah satu proses dalam sistem pendidikan di IPT. Sungguhpun proses ini sukar dibangunkan tetapi inisiatif ini amat penting untuk menentukan sama ada pencapaian kemahiran generik dalam kalangan pelajar IPT wujud atau sebaliknya (Hambur, Rowe \& Luc, 2002).

Kajian tinjauan yang dijalankan oleh Kementerian Sumber Manusia (2005) dan Kementerian Pengajian Tinggi Malaysia (2006) telah mendapati sejumlah 59,315 siswazah mengganggur. Antara faktor utama yang menjadi petunjuk utama pengangguran tersebut ialah kurang kemahiran komunikasi khususnya dalam kemahiran lisan dan kemahiran pemikiran kritikal khususnya dalam penaakulan yang berkaitan penyelesaian masalah. Masalah kurang berkemahiran komunikasi juga dihadapi bagi negara seperti Thailand, Nepal, Taiwan, China, Hong Kong, dan Jepun. Australia juga telah memberi fokus utama bagi menekankan kemahiran generik di kalangan pelajar universiti-universiti di Australia (National Centre for Vocational Education Research NCVER, 2003). Fokus meningkatkan kemahiran kemahiran generik khususnya dalam kemahiran komunikasi dan berfikiran kritikal serta menyelesaikan masalah bukan sahaja menjadi fokus di institusi pendidikan di Malaysia tetapi juga bagi institusi pendidikan di luar negara. Keduadua kemahiran ini merupakan kemahiran yang merentasi kurikulum dan merupakan kemahiran boleh pindah atau transferable skills.

Majikan pada era globalisasi ini lebih menekan kepada keperluan pekerja yang mempunyai kemahiran kompetensi generik yang tinggi dalam kemahiran interpersonal, kepimpinan (Mason 1992; Quek, 1996) kerja berpasukan (Boud \& Middleton, 2003; Kanapathy, 2001), dan kemahiran menulis dan lisan (Jacobsen, 
1993; Schroder, 1989). Tidak ada disiplin yang dikhususkan bagi pembangunan kompetensi kemahiran generik kecuali ianya dibangunkan bersama-sama dalam kursus yang diambil oleh semua pelajar prasiswazah di universiti setiap hari (Siti Rahayah, Noriah, Abdul Ghafar, Rodiah \& Nur Ashiqin, 2008a). Instrumen pentaksiran kemahiran generik perlu bagi mengukur tahap pencapaian kemahiran pelajar sepanjang pengajian mereka di universiti.

Pencapaian akademik adalah sebahagian daripada ukuran kepada kejayaan pelajar mengikut sesuatu kursus di universiti. Walau bagaimanapun tahap kesediaan pelajar untuk mengharungi dunia luar selepas mengikut kursus dengan jayanya di universiti telah menjadi persoalan yang hangat dibincangkan sejak akhir-akhir ini. Pelbagai persoalan timbul berkaitan dengan bagaimanakah pelajar itu belajar, apakah kemahiran generik yang telah diterapkan dan apakah yang memotivasikan mereka untuk belajar dan apakah kaitannya dengan pencapaian mereka (Kementerian Pengajian Tinggi (KPT), 2006).

Organisasi perniagaan dan stakeholders pada masa kini telah menyatakan bahawa kemahiran yang dimiliki oleh pelajar-pelajar universiti kini tidak dapat memenuhi keperluan kemahiran yang diperlukan di tempat kerja akibat perubahan dalam pasaran pekerjaan peringkat globalisasi antarabangsa (ACT, Inc., 2000). Oleh itu, adalah penting untuk menyenaraikan kemahiran-kemahiran yang diperlukan dalam persekitaran kerja pada masa ini, pada masa depan, dan menentukan tahap-tahap kompetensi pelajar-pelajar universiti (Siti Rahayah et al., 2008a) yang perlu dilaksanakan. Berdasarkan maklumat penting ini, pengubal polisi, para pendidik, korporat dan ahli perniagaan boleh menetapkan matlamat untuk mencapai kos efektif peningkatan-peningkatan dalam sistem-sistem pendidikan yang dijangka akan menjana tenaga kerja berkualiti (ACT, Inc., 2000).

Wilhelm (2002) menegaskan terdapat banyak sekolah menengah atasan dan pengajian tinggi tidak menyumbang kepada peningkatan kemahiran generik semasa pengajian mereka. Oleh itu kemahiran generik perlu diterapkan atau diintegrasikan dalam kurikulum dan pelaksanaannya sudah tentu mencabar (Martinez, 2005). Pelajar sendiri perlu mengetahui kemahiran-kemahiran yang menjadi asas atau petunjuk utama dalam kemahiran generik supaya persediaan boleh dijalankan bagi mengilap dan meningkatkan kemahiran dan kompetensi pelajar dalam kemahiran generik. Pihak universiti akan dapat membuat perancangan bagi menerapkan kemahiran-kemahiran utama sedari awal kemasukan pelajar 
pada tahun pertama. Pandangan pihak yang berkepentingan atau stakeholder juga adalah penting bagi menyenaraikan kemahirankemahiran kritikal yang perlu di capai oleh pelajar-pelajar universiti. Oleh itu kajian ini adalah sangat singnifikan dan boleh menjadi panduan bagi pihak universiti, pelajar dan pihak yang berkepentingan untuk mengetahui kemahiran yang memberi pengaruh atau petunjuk yang sangat signifikan dalam kemahiran berfikiran kritikal, menyelesaikan masalah dan komunikasi.

Secara umumnya, kajian ini bertujuan untuk memeriksa 13 konstruk kemahiran generik yang menjadi petunjuk atau memberi pengaruh besar kepada peningkatan kemahiran generik secara keseluruhannya. Dapatan kajian ini akan menjadi petunjuk kepada pihak yang berkaitan dan berkepentingan bagi melaksanakan program intervensi bagi meningkatkan kemahiran-kemahiran yang telah dikenal pasti. Pemboleh ubah tidak bersandar dalam kajian ini ialah kemahiran generik yang terdiri daripada kemahiran Tanggungjawab Sosial, Menghargai Alam Sekitar, Etika, Moral, dan Profesionalisme, Kerohanian, Kepimpinan, Kerja Berpasukan, Teknologi Maklumat dan Komunikasi (ICT), Pembelajaran Sepanjang Hayat, Globalisasi, Keusahawanan, dan Pengurusan. Manakala pemboleh ubah bersandar terdiri daripada dua kemahiran iaitu Komunikasi, Berfikiran Kritikal dan Menyelesaikan Masalah. Objektif khusus kajian ini adalah untuk memeriksa dan menganalisis konstruk-konstruk kemahiran generik ke atas 1,262 pelajar prasiswazah UKM dari aspek (1) korelasi konstruk-konstruk kemahiran generik, (2) faktor petunjuk utama kemahiran generik kepada kemahiran komunikasi, dan (3) faktor petunjuk utama kemahiran generik terhadap kemahiran berfikiran kritikal dan menyelesaikan masalah.

\section{KAJIAN LITERATUR}

Terma generik berasal daripada beberapa istilah yang telah digunakan di serata negara di dunia dalam pelbagai sebutan. Istilah, Kemahiran generik di Singapura disebut sebagai kemahiran kebolehan kritikal (critical enabling skills), sementara di United Kingdom, kemahiran generik disebut sebagai kemahiran asas (core skills), kemahiran kunci (key skills), kemahiran umum (common skills) dan kemahiran boleh pindah (transferable skills). Istilah kemahiran generik telah digunakan di New Zealand dengan istilah kemahiran penting (essential skills) sementara di Australia istilah 
yang digunakan ialah kompetensi kunci (key competencies), kemahiran kebolehpasaran (employability skills) dan kemahiran generik (generic skills). Di Kanada, kemahiran generik menggunakan istilah yang sama seperti di Australia iaitu kemahiran kebolehpasaran sementara di Amerika Syarikat menggunakan istilah kemahiran asas (basic skills) dan kemahiran di tempat kerja (workplace know-how). Di Perancis istilah yang digunakan ialah kemahiran boleh pindah (transferable skills), sementara di Switzerland menggunakan istilah disiplin merentas matlamat (Trans-displinary goals) (Posfas, 2006; NCVER, 2003). Di Malaysia kemahiran ini lebih dikenali sebagai kemahiran generik dan kemahiran insaniah (KPT, 2006).

\section{KEMAHIRAN GENERIK}

KPT (2006) telah mendefinisikan kemahiran insaniah merangkumi aspek-aspek kemahiran generik yang melibatkan elemen kognitif yang berkaitan dengan kemahiran bukan akademik seperti nilai positif, kepimpinan, kerjasama berpasukan, komunikasi dan pembelajaran berterusan.

Quek Ai-Hwa (2005) menjelaskan kompetensi generik perlu dimiliki oleh graduan dalam menempuhi alam pekerjaan. Beliau menyatakan pertimbangan generik amat penting dalam mencapai kejayaan dalam bidang pekerjaan. Tujuan kajian ini dijalankan adalah untuk melihat keberkesanan kompetensi generik untuk diaplikasikan dalam bidang pekerjaan.

Kajian oleh Siti Rahayah et al. (2008a) menunjukkan kemahiran generik perlu diaplikasikan dalam pengajaran dan pembelajaran subjek dan perlu didedahkan dari awal kemasukan pelajar di semester satu pengajian. Pensyarah perlu lebih sensitif dengan kekuatan dan kelemahan pelajar supaya pengajaran dan pembelajaran dapat diterapkan mengikut kebolehan pelajar.

Definisi dan set konstruk kemahiran generik juga adalah berbeza mengikut negara tetapi tujuannya adalah sama iaitu merupakan kemahiran yang diperlukan oleh pelajar untuk menjadi penuntut yang lebih berjaya dan cemerlang dalam bidang akademik, pekerjaan dan aspek lain dalam kehidupan. Kemahiran generik juga merupakan output penting bagi pendidikan universiti (Allan \& Clarke, 2007; Ballantine \& Larres, 2007; Biggs, 2003; Dunne, Bennett, \& Carré, 2000; Jager \& Nassimbeni, 2005: Lizzio \& Wilson, 2004; Lublin, 2003). Menurut Posfas (2006); NCVER (2003), walaupun definisi kemahiran generik ini berbeza mengikut 
negara tetapi secara kolektifnya kemahiran ini mengukur enam elemen yang sama iaitu (1) basic/fundamental skills, (2) peoplerelated skills, (3) conceptual/thinking skills, (4) personal skills and attributes, (5) skills related to the business world, dan (6) skills related to the community.

Universiti sebagai IPT harus menjadi tempat yang paling sesuai untuk menggilap kemahiran generik pelajar (Allan \& Clarke, 2007; Ballantine \& Larres, 2007; Biggs, 2003; Dunne, Bennett, \& Carré, 2000; Jager \& Nassimbeni, 2005; Lizzio \& Wilson, 2004; Lublin, 2003; Siti Rahayah, Rodiah \& Noriah, 2008e). Pelajar IPT pula perlu mempunyai keinginan dan keupayaan untuk melibatkan diri dalam proses pembentukan modal insan dengan minda kelas pertama ini. Justeru, penerapan kemahiran generik mesti dilaksanakan secara menyeluruh oleh universiti dengan melibatkan semua pihak yang ada hubungan dengan pelajar.

\section{KEMAHIRAN BERFIKIRAN KRITIKAL DAN MENYELESAIKAN MASALAH}

Pencapaian akademik pelajar dipengaruhi dengan beberapa kemahiran generik (Trueman \& Hartley, 1996). Sebagai contoh kemahiran berfikiran kritikal, menyelesaikan masalah dan komunikasi. Kedua-dua kemahiran ini mempunyai pengaruh rapat dan petunjuk bagi pencapaian akademik pelajar. Fisher dan Scriven (1997) menyatakan pemikiran kritikal sebagai kemahiran mentafsir dan menilai sesuatu perkara yang diperhatikan dan maklumat yang diterima serta hujahan yang diperoleh dalam sesuatu komunikasi. Pelajar yang kurang mahir dalam kemahiran komunikasi menulis dan lisan ada hubungan dengan pencapaian akademik yang rendah (Gardner, Milne, Stringer \& Whiting, 2005). Pelajar yang memasuki universiti atau institusi pengajian tinggi yakin mereka mempunyai kemahiran generik tetapi tidak tahu bagaimana untuk mempertingkatkan kemahiran tersebut atau mengaplikasi kemahiran tersebut dalam akademik dan kehidupan di universiti (Lowe \& Cook, 2003; Richardson, 2003). Terdapat hubungan yang signifikan antara kemahiran komunikasi interpersonal dengan pencapaian pelajar (Kamarudin, 2003; Murphy, 2001; Richardson, 2003). Pelajar yang mempunyai kemahiran komunikasi adalah pelajar yang boleh berkomunikasi dengan baik dengan tenaga pengajar, rakanrakan dalam kumpulan, mengeluarkan idea dan pendapat, menulis dengan baik semasa peperiksaan, dan boleh membentangkan hasil 
kajian dengan baik semasa menjalankan tugasan yang diperlukan sepanjang pengajian mereka.

Ramai pakar pemikiran kritikal cenderung mendefinisikan pemikiran kritikal di perlukan bagi menyelesaikan sesuatu masalah dalam akademik dan juga dalam kehidupan. Ennis (1996) menyatakan pemikiran kritikal adalah satu set kemahiran yang diperlukan bagi menyelesaikan masalah yang kompleks. Pemikiran kritikal adalah fokus bagi seseorang untuk mempercayai atau melakukan sesuatu perkara (Ennis, 1996). Kemahiran ini perlu dikuasai oleh pelajarpelajar khususnya di institusi pengajian tinggi kerana pelajar perlu menilai, menjana, menaakul, menganalisis dan memilih maklumat yang diterima bagi membuat keputusan atau melaksanakan tugasan yang diserahkan kepada mereka. Pelajar sering mencari dan memerlukan bahan bagi menyelesaikan tugasan sepanjang mereka berada di universiti, oleh itu kemahiran menyaring dan memilih bahan yang berkualiti adalah diperlukan bagi menghasilkan satu tugasan yang bermutu.

Bennis (1995) mendefinisikan pemikiran kritikal sebagai pembelajaran yang berkaitan dengan pemikiran, bagaimana menggunakan dan menghubungkannya supaya menjadikan lebih bermakna. Organ (1965) menyatakan pemikiran kritikal sebagai penggunaan kepintaran bagi membuat keputusan. Norris dan Ennis (1989) mentakrifkan bahawa pemikiran kritis adalah sebagai pemikiran yang munasabah dan reflektif, iaitu yang memberi tumpuan kepada menentukan tindakan yang sewajarnya dibuat dan dipercayai. Norris (1992) mentafsir pemikiran kritis sebagai membuat keputusan secara rasional tentang perkara yang hendak dipercayai atau tidak. Mertes (1991) mentafsir pemikiran kritis sebagai gabungan proses sedar dan sengaja yang digunakan untuk menilai maklumat dan pengalaman, serta satu set sikap dan kebolehan refleksi yang memandu kepercayaan dan tindakan. Huitt (2007) mentafsir pemikiran kritis sebagai aktiviti mental berdisiplin bagi menilai hujah dalam membuat pertimbangan ke arah pelaksanaan tindakan. Browne dan Keeley (2000), mentafsir pemikiran kritis sebagai suatu proses yang bermula dengan satu hujah kepada proses penilaian. Paul dan Elder (2001), mentakrif pemikiran kritis sebagai kebolehan pemikir untuk mengawal pemikiran mereka. Seorang pemikir yang kritis cenderung membuat sesuatu dengan betul, jujur, dan jelas (Ennis, 2000). Pemikiran kritis mempunyai keupayaan untuk membuat sesuatu keputusan atau untuk mencapai rumusan kesimpulan mengenai masalah-masalah dan isu-isu yang mungkin tidak seharusnya mempunyai satu jawapan yang betul (Churchman, 1971). Kemahiran penyelesaian masalah pula 
merupakan satu matlamat, yang memperlihatkan pelajar dapat mengatasi halangan-halangan yang datang dengan menggunakan strategi dan penilaian terhadap keputusan yang diambil. Kemahiran penyelesaian masalah perlu ada dalam setiap diri pelajar untuk membentuk jati diri supaya lebih cekap dan berkesan (Bjorkland \& Pellegrini, 2000). Penyelesaian masalah adalah peringkat paling tinggi proses kognitif yang memerlukan modulasi dan mengawal lebih kemahiran-kemahiran rutin atau kemahiran asas yang lain (Goldstein \& Levin, 1987). Walaupun pelbagai tafsiran tentang berfikiran kritikal dan menyelesaikan masalah dilakukan namun konsep utamanya berlandaskan kepada membuat penilaian atau pemprosesan maklumat secara rasional ke arah membuat sesuatu keputusan dan merupakan kemahiran yang perlu diterapkan dalam semua disiplin pengajian.

Semua takrif-takrif ini, melibatkan kesedaran dan pendekatan tertentu bagaimana untuk menangani isu atau menyelesaikan sesuatu masalah khusus. Dalam konteks pengajian di institusi pendidikan, pemikiran kritis dan menyelesaikan masalah mencerminkan keupayaan pelajar-pelajar bagi mengenal pasti isu-isu dan mencadangkan penyelesaian-penyelesaian semasa menjalankan analisis, kajian, dan pemilihan bahan dalam melaksanakan tugasan yang diberikan. Manakala kebanyakan universiti di Australia telah memilih kemahiran pemikiran kritikal, penyelesaian masalah dan komunikasi (interpersonal dan penulisan) sebagai asas kepada kemahiran-kemahiran yang lain dan merupakan kemahiran boleh pindah (transferable) serta mudah diukur. Kemahiran ini juga menjadi fokus penting bagi universiti, agensi kerajaan dan majikan di negara-negara lain (Hambur, Rowe \& Luc, 2002).

Kebolehan menilai merupakan asas kepada pemikiran kritis dan menyelesaikan masalah; iaitu menilai idea, bukti cadangan, tindakan dan penyelesaian. Pelajar yang berfikir dengan kritis membuat penilaian sama ada hendak menerima sesuatu alasan itu sebagai munasabah; menggunakan kriteria atau nilai tara yang dipersetujui untuk menilai alasan berkenaan, menggunakan pelbagai strategi penaakulan dalam pelaksanaan kriteria atau standard tersebut; dan mencari maklumat yang boleh dipercayai sebagai bukti yang menyokong keputusan yang dibuat. Tujuan mengajar pemikiran kritikal adalah supaya individu-individu boleh berfikir secara adil, objektif dan sentiasa jelas dan tepat dalam tindaktanduknya. Pelajar yang diajar berfikir secara kritis; belajar cara menyoal; iaitu, bila hendak menyoal dan jenis soalan yang hendak ditanya dan belajar bagaimana menaakul; iaitu, bila menggunakan 
penaakulan dan kaedah penaakulan yang hendak digunakan (Fisher \& Scriven, 1997)

Dalam konteks kajian ini kemahiran berfikiran kritikal dan menyelesaikan masalah ialah (1) mengenal pasti dan mensintesis masalah dengan tepat; (2) menjana bukti dan data yang menyokong dengan tepat dan menyeluruh; (3) membezakan dengan jelas fakta dengan pendapat; (4) mengenal pasti konteks serta skop isu/permasalahan yang dikaji dengan jelas; (5) mengenal pasti kemungkinan-kemungkinan bias; (6) menjana keputusan dengan tepat; (7) menjelaskan implikasi keputusan yang dijana; mempersembahkan refleksi terhadap keputusan secara objektif.

\section{KEMAHIRAN KOMUNIKASI}

Terdapat pelbagai definisi oleh pakar berkaitan dengan komunikasi, dan kemahiran ini juga penting dan perlu diintegrasi dalam semua disiplin pengajian. Komunikasi adalah interaksi sosial melalui berita atau pesanan (Fiske, 1990). Komunikasi adalah proses perkongsian maklumat antara seseorang dengan seseorang yang lain bagi meningkatkan kefahaman (Rogers, 1995). Komunikasi adalah aktiviti penghantaran kandungan simbol semata-mata daripada satu sumber ke suatu sumber yang lain, tetapi ditukar di antara ejen manusia, yang berinteraksi di dalam perkongsian situasi atau konteks percakapan (Price, 1997). Komunikasi adalah satu proses yang dilakukan oleh manusia dalam sesuatu kumpulan berdasarkan budaya setempat bagi mewujudkan keadaan yang realiti (Trenholm, 1999). Komunikasi adalah satu proses perhubungan yang kadangkala boleh diramalkan berdasarkan pada mesej yang dihantar dan mesej yang diterima. Menurut Eunson (2007), komunikasi merupakan agen utama yang mengukuhkan hubungan dalam sesuatu organisasi. Altman dan Taylor (1973) dalam teori tembusan sosial: komunikasi (social penetration theory), menyatakan dalam proses menjalin hubungan, komunikasi berubah daripada tahap cetek, tidak intim kepada tahap yang lebih mendalam dan peribadi dalam jangka masa tertentu. Manakala menurut Berger (1985) dalam teori pengurangan ketidakpastian (uncertainty reduction theory) memberi tumpuan terhadap komunikasi manusia bagi mendapatkan pengetahuan dan membentuk persefahaman di antara satu sama lain. Sebahagian definisi menekankan aspek sosial dan budaya bagi komunikasi, dan sebahagiannya pula memberi fokus kepada aspek behaviourisme dan kognitif. 
Komunikasi penting untuk meningkatkan pertukaran dan perkongsian pengetahuan, kemahiran dan kebolehan yang boleh memberi faedah kepada pengajar dan pelajar (Berscheid, 1994; Fiske, 1990; Young \& Perrewe, 2000). Sesungguhnya amalan komunikasi antara pengajar dan pelajar penting (Young \& Perrewe, 2000). Menurut Dench (1997) kemahiran komunikasi amat penting dalam mempengaruhi keberkesanan seseorang individu yang berkemampuan dalam mengendalikan tempat kerja. Beliau menyatakan individu yang mempunyai kemahiran komunikasi merupakan satu kelebihan untuk individu tersebut bersaing di pasaran kerja yang begitu kompleks.

Kinnick dan Parton, (2005) dalam kajian mereka mendapati bahawa kemahiran komunikasi seperti kemahiran interpersonal, lisan, dan kebolehan berbincang atau berinteraksi mempunyai hubungan yang kuat atau dipengaruh kuat oleh kemahiran kepimpinan.

Pincus dan DeBonis, (2004), menyatakan bahawa kandungan dalam kepimpinan adalah inti pati atau pengaruh utama dalam proses komunikasi kerana kedua kemahiran ini adalah kekuatan perhubungan sesama manusia bagi meningkatkan kesefahaman dan kepercayaan. Takrifan dan konsep komunikasi adalah ditakrifkan juga sebagai kepimpinan dan kedua-dua kemahiran ini adalah saling melengkapi (Conrad \& Poole, 2002; Eisenberg \& Goodall, 2004; O'Hair, Friedrich, \& Dixon, 2002; Shockley-Zalabak, 2002).

Fokus kemahiran komunikasi dalam kajian ini adalah (1) kebolehan menunjukkan kemahiran bukan lisan yang berkesan (gerak tubuh, nada suara); (2) kebolehan memberi maklum balas terhadap isu-isu yang dikemukakan pada setiap peringkat melalui saluran yang sedia ada; (3) menyampaikan idea secara lisan dengan berkesan; (4) menyampaikan idea secara bertulis dengan berkesan; (5) membuat pembentangan secara meyakinkan dan berkesan; (6) menunjukkan kebolehan melakukan perundingan sehingga mencapai matlamat yang dikehendaki; (7) menunjukkan kebolehan berinteraksi secara berkesan; (8) menunjukkan kebolehan membuat rumusan dengan berkomunikasi.

Komunikasi adalah penting untuk meningkatkan pertukaran dan perkongsian pengetahuan, kemahiran dan kebolehan yang boleh memberi faedah kepada pengajar dan pelajar (Berscheid, 1994; Fiske, 1990; Young \& Perrewe, 2004). Kemahiran komunikasi juga sama seperti kemahiran berfikiran kritikal dan menyelesaikan masalah yang perlu dikuasai oleh semua pelajar di institusi pengajian atau pendidikan. Kemahiran komunikasi adalah merentasi kurikulum dan setiap pelajar sering mempraktikkan kemahiran komunikasi 
sepanjang pengajian di institusi pengajian tinggi dan juga dalam kehidupan seharian. Dalam konteks akademik, pelajar sering menggunakan elemen-elemen penting dalam komunikasi seperti mendengar apa yang diajar oleh tenaga pengajar dalam kuliah yang dihadiri. Pelajar akan berinteraksi secara lisan dalam perbincangan kumpulan. Tugasan atau kerja kursus merupakan perkara yang sering dilakukan oleh pelajar, oleh itu pelajar perlu menguasai kemahiran menulis dalam bentuk yang lebih ilmiah. Pelajar juga sering diminta untuk membentangkan hasil tugasan yang diberikan sama ada secara kumpulan ataupun individu. Oleh itu pelajar perlu yakin berhadapan dengan khayalak ramai dan berani untuk berhujah bagi mempertahankan hasil kajian mereka.

\section{METODOLOGI KAJIAN}

Kajian tinjauan secara kuantitatif digunakan dalam penyelidikan ini. Menurut Creswell, (2008), populasi kajian bermaksud satu kumpulan individu yang mewakili kriteria yang sama dengan tujuan kajian yang dijalankan. Sampel pula adalah subkumpulan daripada populasi yang disasarkan oleh pengkaji, dan dapatan kajian yang dijalankan ke atas sampel mampu mewakili keseluruhan populasi (Creswell, 2008). Populasi dalam kajian ini ialah 16,189 pelajarpelajar ijazah pertama Universiti Kebangsaan Malaysia. Terdapat 12 fakulti pengajian iaitu: (1) Ekonomi dan Perniagaan; (2) Farmasi; (3) Kejuruteraan dan Alam Bina; (4) Pendidikan; (5) Pengajian Islam; (6) Pergigian; (7) Perubatan; (8) Sains dan Teknologi; (9) Sains Kesihatan Bersekutu; (10) Sains Sosial dan Kemanusiaan; (11) Teknologi dan Sains Maklumat; dan (12) Undang-undang. Pengkaji menggunakan prosedur persampelan kelompok (clustered) berdasarkan 12 fakulti pengajian yang terdapat di UKM. Menurut Gay dan Airasian (2003), kaedah persampelan kelompok ini adalah kaedah paling praktikal dan senang diuruskan dalam kajian-kajian pendidikan. Pengkaji telah memilih seramai 100 orang pelajar bagi setiap fakulti pengajian secara rawak berstrata yang mempunyai sub-sub sampel seperti jantina, bangsa, dan aliran. Kajian ini melibatkan seramai 1,262 sampel pelajar prasiswazah. Sampel kajian terdiri daripada setiap kluster iaitu gender, bangsa, dan aliran. Jumlah sampel pelajar perempuan ialah seramai 885 (70.1\%) dan lelaki 377 (29.9\%). Jumlah pelajar Melayu ialah 927 (73.5\%), Cina 249 (19.7\%), India 52 (4.1\%) dan lain-lain 34 (2.7\%). Pelajar aliran sains berjumlah $665(52.7 \%)$ manakala aliran bukan sains ialah 597 $(47.3 \%)$. 
Instrumen Kemahiran Generik Pengajian Tinggi atau Generic Skills Instrument for Higher Education (GeSIHE, 2008) telah digunakan dalam kajian ini. Instrumen GeSIHE yang dibina oleh sekumpulan penyelidik di UKM telah digunakan untuk mengukur kemahiran generik pelajar. GeSIHE digunakan bagi mengukur 13 kemahiran generik dengan 102 item yang terdiri daripada (1) Tanggungjawab Sosial (TSosial-7 item), (2) Menghargai Alam Sekitar (ASekitar-5 item), (3) Etika, Moral dan Profesionalisme (EtikaMP-5 item), (4) Kerohanian (Rohani-6 item), (5) Komunikasi (Kom-13 item), (6) Kepimpinan (Pimpin-10 item), (7) Kerja Berpasukan (KBerpasukan-9 item), (8) Berfikiran Kritikal dan Menyelesaikan Masalah (BKritikalMM-10 item), (9) Teknologi Maklumat dan Komunikasi (ICT-7 item), (10) Pembelajaran Sepanjang Hayat (PSHayat-12 item), (11) Globalisasi (Global-7 item), (12) Keusahawanan (Usahawan-6 item) dan (13) Pengurusan (Pengurus-5 item). GeSIHE adalah instrumen skala likert lima mata (tidak mantap, kurang mantap, sederhana, baik dan sangat baik) yang telah dibina menggunakan model pengukuran Rasch dan Model Persamaan Struktural. Kebolehpercayaan GeSIHE yang berdasarkan skala logits menggunakan perisian winsteps 3.64.2 adalah 0.98 bagi kebolehpercayaan responden dan 0.99 kebolehpercayaan item.

Analisis multi-regresi ialah satu teknik statistikal yang digunakan untuk menganalisis perhubungan antara pemboleh ubah bersandar (criterion) dan beberapa pemboleh ubah peramal (predictor). Objektif analisis multi-regresi adalah untuk menggunakan pemboleh ubah tidak bersandar yang memberi nilai untuk meramal nilai tunggal bersandar yang dipilih oleh pengkaji (Hair et al., 2006). Prosedur stepwise mempunyai kelebihan berbanding dengan multi-regresi lain kerana lebih ekonomi dan hanya pemboleh ubah peramal yang signifikan dimasukkan ke dalam regresi (Dekkhoff, 1992). Stepwise dapat menggelakkan masalah multicollinearity yang wujud akibat korelasi yang kuat antara pemboleh ubah-pemboleh ubah peramal. Pemboleh ubahpemboleh ubah yang bermasalah tidak akan dimasukkan ke dalam model regresi (Hair, Anderson, Tantham \& Black, 2006).

\section{DAPATAN KAJIAN}

Data dianalisis menggunakan Winsteps versi 3.64.2 untuk menguji kesahan dan kebolehpercayaan GeSIHE. Analisis model pengukuran Rasch menyediakan kebolehpercayaan responden dan item pada 
Jadual 1 dan 2. Jadual 1 menunjukkan indeks kebolehpercayaan responden iaitu 0.98. Kebolehpercayaan responden menunjukkan tafsiran yang setara dengan Cronbach Alpha atau KR20 (Wright \& Master, 1982). Indeks kebolehpercayaan responden 0.98 adalah nilai yang diterima baik (Pallant 2001; Sekaran 2003) bagi jangkaan ketekalan tahap penyusunan di atas skala logit bagi jawapan pada set item yang berbeza tetapi mengukur konstruk yang sama (Wright \& Masters, 1982). Indeks pengasingan responden adalah 6.37 yang menunjukkan 6 tahap keupayaan responden yang dikesan dalam kajian ini. Keadaan ini juga menunjukkan ukuran kebolehan responden yang merentasi item-item GeSIHE adalah tersebar kepada 6 aras persetujuan. Nilai ini adalah memenuhi kehendak Linacre (2007) menyatakan kebolehpercayaan responden $\geq 0.8$ dan indeks pengasingan responden $\geq 2.0$ adalah indeks yang diterima baik.

Jadual 1

Kebolehpercayaan Responden GeSIHE

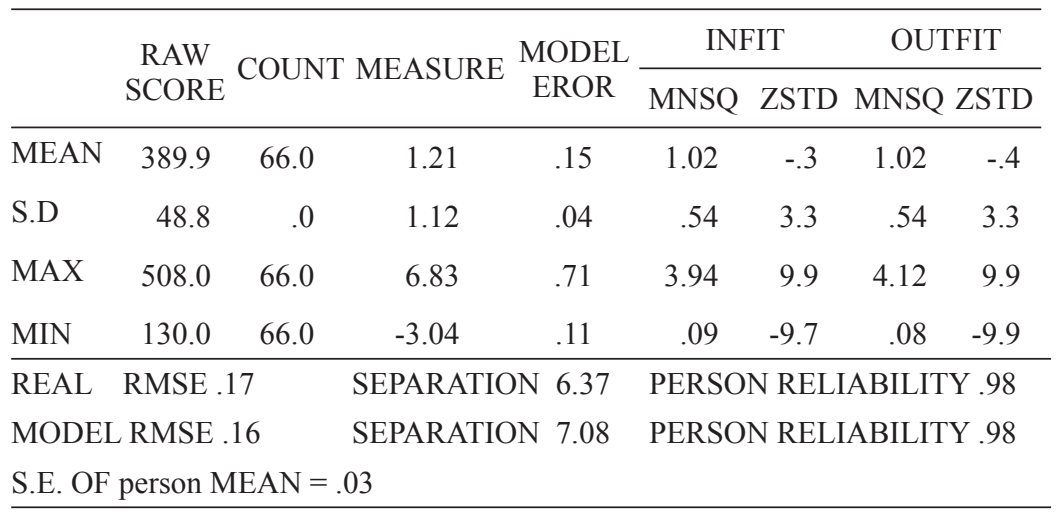

(Summary of 1262 Measured Persons)

Jadual 2 menunjukkan indeks kebolehpercayaan item ialah 0.99. Nilai 0.99 ini adalah tinggi dan sangat baik kerana menghampiri 1.0 (Wright \& Masters, 1982). Hal ini bermakna jangkaan pengulangan bagi item GeSIHE ini adalah juga tinggi sekiranya ditadbir kepada kumpulan responden yang lain dengan keupayaan yang sama (Wright \& Maters, 1982). Indeks pengasingan item ialah 10.59, yang bermaksud item GeSIHE secara statistikal adalah dibahagikan kepada 10 strata atau aras persetujuan. Keadaan ini juga menunjukkan item-item ini adalah 10 kali lebih tersebar dari ralat punca kuasa dua. 
Jadual 2

Kebolehpercayaan Item GeSIHE

\begin{tabular}{|c|c|c|c|c|c|c|c|c|}
\hline & \multirow{2}{*}{$\begin{array}{c}\text { RAW } \\
\text { SCORE }\end{array}$} & \multirow{2}{*}{ COUNT } & \multirow{2}{*}{ MEASURE } & \multirow{2}{*}{$\begin{array}{c}\text { MODEL } \\
\text { EROR }\end{array}$} & \multicolumn{2}{|c|}{ INFIT } & \multicolumn{2}{|c|}{ OUTFIT } \\
\hline & & & & & MNSQ & ZSTD & MNSQ & ZSTD \\
\hline MEAN & 4824.6 & 1262.0 & .00 & .04 & 1.00 & -.9 & 1.02 & -.6 \\
\hline S.D & 282.6 & .0 & .48 & .00 & .33 & 6.2 & .34 & 6.1 \\
\hline MAX & 5390 & 1262.0 & 1.53 & .05 & 2.40 & 9.9 & 2.55 & 9.9 \\
\hline MIN & 2715.0 & 1262.0 & -1.13 & .03 & .55 & -9.9 & .58 & -9.9 \\
\hline REAL & \multicolumn{2}{|c|}{ RMSE .04 } & \multicolumn{2}{|c|}{ SEPARATION 10.59} & \multicolumn{4}{|c|}{ PERSON RELIABILITY .99 } \\
\hline \multicolumn{3}{|c|}{ MODEL RMSE .04 } & \multicolumn{2}{|c|}{ SEPARATION 11.29} & \multicolumn{4}{|c|}{ PERSON RELIABILITY .99 } \\
\hline \multicolumn{9}{|c|}{ S.E. OF person MEAN $=.05$} \\
\hline
\end{tabular}

(Summary of 102 Measured Items)

Jadual 3 adalah keputusan Pekali Korelasi Pearson, yang menunjukkan kesemua pasangan pemboleh ubah mempunyai korelasi yang +ve signifikan pada aras 0.01 (2-tailed). Terdapat tiga pasangan pemboleh ubah menunjukkan korelasi yang sangat tinggi atau sangat kuat iaitu Pengurusan-Keusahawanan (.83; $\left.\mathrm{r}^{2}=.68\right)$, KBerpasukan-Kepimpinan $\left(.72 ; \mathrm{r}^{2}=.52\right)$, dan BKritikalMM-PSHayat $\left(.71 ; \mathrm{r}^{2}=.51\right)$. Pasangan Kemahiran Kom-Kpim menunjukkan korelasi yang tinggi $\left(.67 ; \mathrm{r}^{2}=.45\right)$. Terdapat 2 pasangan korelasi rendah atau lemah iaitu Globalisasi-TSosial $\left(.27 ; \mathrm{r}^{2}=.07\right)$ dan Globalisasi- Alam Sekitar $\left(.24 ; \mathrm{r}^{2}=.06\right)$. Indeks korelasi pasangan pemboleh ubah yang lain menunjukkan tahap korelasi sederhana dan kuat atau kukuh di antara .31 hingga .70. Pemboleh ubah kajian ini yang melibatkan konstruk komunikasi dan berfikiran kritikal serta menyelesaikan masalah adalah pemboleh ubah yang menunjukkan korelasi yang tinggi dibandingkan dengan pemboleh ubah yang lain.

Jadual 4 menunjukkan skor min 13 konstruk GeSIHE, secara keseluruhannya, konstruk TSosial (4.10) menunjukkan min tertinggi, diikuti dengan Alam Sekitar, KBerpasukan, Kepimpinan, PSHayat, EtikaMP, ICT, BKritikalMM, Keusahawanan, Kerohanian, Komunikasi, Pengurusan, dan skor min paling rendah ialah Globalisasi (min=4.10, 4.04, 3.99, 3.96, 3.92, 3.79, 3.78, 3.77, $3.74,3.73,3.70,3.61,3.49)$. 


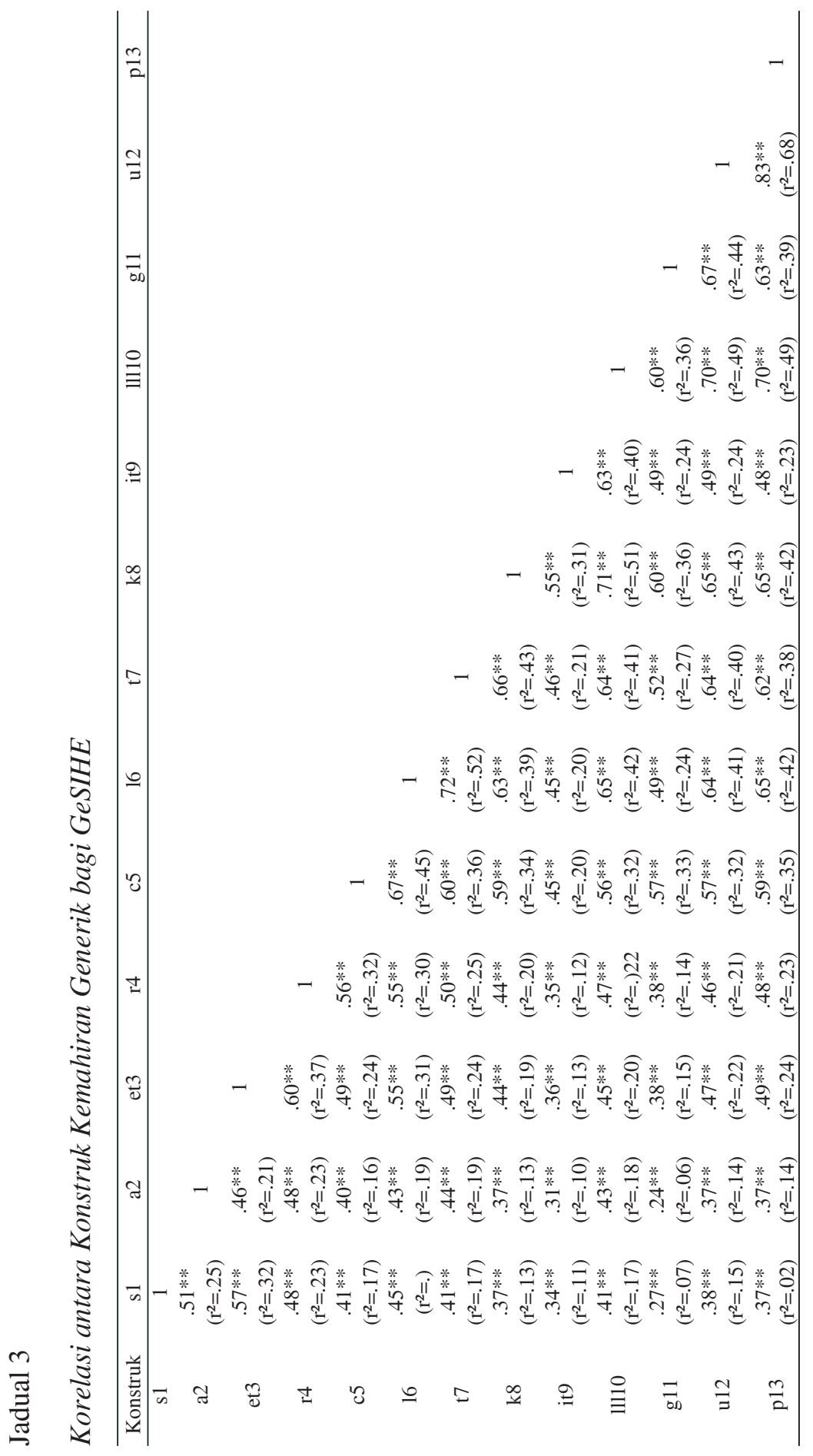


Jadual 4

Statistik Deskriptif Konstruk Kemahiran Generik N=1262

\begin{tabular}{lcc}
\hline \multirow{2}{*}{ Konstruk } & Min & \multicolumn{2}{c}{ Sisihan Piawai } \\
\cline { 2 - 3 } & \multicolumn{2}{c}{$\mathrm{N}=1262$} \\
\hline TSosial & 4.10 & .64 \\
Alam Sekitar & 4.04 & .66 \\
EtikaMP & 3.79 & .84 \\
Kerohanian & 3.73 & .75 \\
Komunikasi & 3.70 & .55 \\
Kepimpinan & 3.96 & .52 \\
KBerpasukan & 3.99 & .51 \\
BKritikalMM & 3.77 & .57 \\
ICT & 3.78 & .62 \\
PSHayat & 3.92 & .55 \\
Globalisasi & 3.49 & .77 \\
Keusahawanan & 3.74 & .85 \\
Pengurusan & 3.61 & .89 \\
\hline
\end{tabular}

\section{Pengaruh Kemahiran Generik Kepada Kemahiran Komunikasi}

Jadual 5 menunjukkan enam pemboleh ubah peramal daripada 12 jumlah keseluruhan pemboleh ubah dalam kemahiran generik bagi pemboleh ubah kriterion komunikasi iaitu (1) kepimpinan, (2) Globalisasi, (3) Kerohanian, (4) BKritikalMM, (5) KBerpasukan, dan (6) ICT yang dimasukkan ke dalam model regresi pada aras $\mathrm{p}$ $\leq .05$. Oleh itu petunjuk utama atau kemahiran yang menunjukkan pengaruh yang besar bagi kemahiran komunikasi ialah kemahiran kepimpinan.

Jadual 5

Variable Entered/Removed (a)

\begin{tabular}{cccl}
\hline Model & $\begin{array}{c}\text { Variable } \\
\text { Entered }\end{array}$ & $\begin{array}{c}\text { Variables } \\
\text { Removed }\end{array}$ & \multicolumn{1}{c}{ Method } \\
\hline $1 . \quad$ & Kepimpinan & - & $\begin{array}{l}\text { Stepwise (Criteria: Probalility-of-F- } \\
\text { to-enter } \leq .05, \text { Probability-of-F-to- } \\
\text { remove } \geq .10)\end{array}$ \\
& Globalisasi & - & $\begin{array}{l}\text { Stepwise (Criteria: Probalility-of-F- } \\
\text { to-enter } \leq .05, \text { Probability-of-F-to- } \\
\text { remove } \geq .10)\end{array}$ \\
\hline
\end{tabular}

(sambungan) 


\begin{tabular}{|c|c|c|c|}
\hline Model & $\begin{array}{l}\text { Variable } \\
\text { Entered }\end{array}$ & $\begin{array}{l}\text { Variables } \\
\text { Removed }\end{array}$ & Method \\
\hline 3. & Kerohanian & - & $\begin{array}{l}\text { Stepwise (Criteria: Probalility-of-F- } \\
\text { to-enter } \leq .05 \text {, Probability-of-F-to- } \\
\text { remove } \geq .10 \text { ) }\end{array}$ \\
\hline 4. & BKritikalMM & - & $\begin{array}{l}\text { Stepwise (Criteria: Probalility-of-F- } \\
\text { to-enter } \leq .05 \text {, Probability-of-F-to- } \\
\text { remove } \geq .10 \text { ) }\end{array}$ \\
\hline 5. & KBerpasukan & - & $\begin{array}{l}\text { Stepwise (Criteria: Probalility-of-F- } \\
\text { to-enter } \leq .05 \text {, Probability-of-F-to- } \\
\text { remove } \geq .10 \text { ) }\end{array}$ \\
\hline 6. & ICT & - & $\begin{array}{l}\text { Stepwise (Criteria: Probalility-of-F- } \\
\text { to-enter } \leq .05 \text {, Probability-of-F-to- } \\
\text { remove } \geq .10 \text { ) }\end{array}$ \\
\hline
\end{tabular}

Pemboleh ubah Bersandar : Komunikasi

Jadual 6 menunjukkan kolerasi antara pemboleh ubah kriterion dan pemboleh ubah peramal kepimpinan ialah .67, korelasi antara pemboleh ubah kriterion dan kombinasi antara kepimpinan dan globalisasi ialah .53. Manakala korelasi pemboleh ubah kriterion dan kombinasi linear antara keenam-enam pemboleh ubah peramal kepimpinan, globalisasi, kerohanian, BKritikalMM, KBerpasukan dan ICT ialah .76. Nilai $\mathrm{R}^{2}$ sebanyak .45 menunjukkan bahawa $45 \%$ perubahan dalam pemboleh ubah kriterion komunikasi adalah disebabkan oleh perubahan dalam kepimpinan. Kombinasi kepimpinan dan globalisasi menyumbangkan sebanyak 8\% (.53-.45) $\%$ iaitu $7.7 \%$ perubahan tambahan dalam komunikasi. Manakala kerohanian, BKritikalMM, KBerpasukan dan ICT masing-masing menyumbang sebanyak $3.8 \%, 0.7 \%, 0.2 \%$, dan $0.1 \%$ varians dalam komunikasi. Manakala kombinasi linear keenam-enam pemboleh ubah peramal tersebut menyumbang sebanyak $58 \%$ varians dalam pemboleh ubah kriterion komunikasi.

Jadual 6

Ringkasan Model Regresi Kemahiran Komunikasi

\begin{tabular}{ccccc}
\hline Model & $\mathrm{R}$ & $\mathrm{R}^{2}$ & Adjusted $^{2}$ & Anggaran Ralat Piawai \\
\hline 1. & $0.67(\mathrm{a})$ & 0.45 & 0.45 & 0.41 \\
2. & $0.73(\mathrm{~b})$ & 0.53 & 0.53 & 0.38 \\
3. & $0.75(\mathrm{c})$ & 0.57 & 0.56 & 0.36 \\
4. & $0.76(\mathrm{~d})$ & 0.57 & 0.57 & 0.36 \\
5. & $0.76(\mathrm{e})$ & 0.57 & 0.57 & 0.36 \\
6. & $0.76(\mathrm{f})$ & 0.58 & 0.57 & 0.36 \\
\hline \multicolumn{5}{r}{} \\
\end{tabular}



a. Peramal (tetap) : Kepimpinan.
b. Peramal (tetap) : Kepimpinan, Globalisasi.
c. Peramal (tetap) : Kepimpinan, Globalisasi, Kerohanian.
d. Peramal (tetap) : Kepimpinan, Globalisasi, Kerohanian, B Kritikal MM.
e. Peramal (tetap) : Kepimpinan, Globalisasi, Kerohanian, B Kritikal MM, K Berpasukan.
f. Peramal (tetap) : Kepimpinan, Globalisasi, Kerohanian, B Kritikal MM, K Berpasukan, ICT.
g. Pemboleh ubah Bersandar : Komunikasi.

Jadual 7 pada model 6 adalah keputusan nilai-F $(6,1255)=$ $283.46, \mathrm{p}<.05)$ menunjukkan bahawa terdapat perhubungan antara keenam-enam pemboleh ubah peramal tersebut dengan pemboleh ubah kriterion pada aras signifikan $\mathrm{p}<.05$. Nilai ini menunjukkan $58 \%$ sumbangan enam konstruk tersebut (Kepimpinan, Globalisasi, Kerohanian, BKritikalMM, KBerpasukan dan ICT) terhadap varians kemahiran komunikasi adalah signifikan. Keadaan ini jelas menunjukkan bahawa kemahiran kepimpinan adalah faktor besar yang mempengaruhi peningkatan dalam kemahiran komunikasi pelajar.

\section{Jadual 7}

Analisis Varians Kemahiran Komunikasi

\begin{tabular}{llrrrrr}
\hline Model & & $\begin{array}{c}\text { Sum of } \\
\text { Squares }\end{array}$ & df & $\begin{array}{c}\text { Mean } \\
\text { Square }\end{array}$ & F & Sig \\
\hline 1. & Regression & 169.93 & 1 & 169.93 & 1028.84 & $0.01(\mathrm{a})$ \\
& Residual & 208.10 & 1260 & .17 & & \\
T.tal & 378.03 & 1261 & & & \\
& Regression & 199.34 & 2 & 99.67 & 702.25 & $0.01(\mathrm{~b})$ \\
& Residual & 178.69 & 1259 & .14 & & \\
3. & Total & 378.03 & 1261 & & & \\
& Regression & 213.53 & 3 & 71.18 & 544.29 & 0.01 (c) \\
& Residual & 164.50 & 1258 & .13 & & \\
4. & Total & 378.03 & 1261 & & & \\
& Regression & 216.27 & 4 & 54.07 & 420.15 & $0.01(\mathrm{~d})$ \\
& Residual & 161.76 & 1257 & .13 & & \\
5. & Total & 378.03 & 1261 & & & \\
& Regression & 217.01 & 5 & 43.40 & 338.53 & $0.01(\mathrm{e})$ \\
& Residual & 161.02 & 1256 & .13 & & \\
6. & Total & 378.03 & 1261 & & & \\
& Regression & 217.52 & 6 & 36.25 & 283.46 & 0.01 (f) \\
& Residual & 160.51 & 1255 & .13 & & \\
\hline
\end{tabular}

(sambungan) 

a. Peramal (tetap) - Kepimpinan.
b. Peramal (tetap) - Kepimpinan, Globalisasi.
c. Peramal (tetap) - Kepimpinan, Globalisasi, Kerohanian.
d. Peramal (tetap) - Kepimpinan, Globalisasi, Kerohanian, BKritikalMM.
e. Peramal (tetap) - Kepimpinan, Globalisasi, Kerohanian, BKritikalMM, KBerpasukan.
f. Peramal (tetap) - Kepimpinan, Globalisasi, Kerohanian, BKritikalMM, KBerpasukan, ICT
g. Pemboleh ubah Bersandar : Komunikasi

Jadual 8 menunjukkan nilai pekali regresi b bagi keenamenam pemboleh ubah peramal dalam bentuk kombinasi linear. Nilai $\beta$ mewakili pekali regresi piawai bagi keenam-enam pemboleh ubah peramal tersebut dalam bentuk kombinasi linear. Manakala nilai-t menunjukkan keputusan yang signifikan pada $\mathrm{p}<.05$. Dengan itu, multiple linear regression adalah:

ZKomunikasi $=(0.32)$ ZKepimpinan $+(0.22)$ ZGlobalisasi $+(0.21)$ ZKerohanian + (0.09) ZBKritikal MM + (0.07) ZKBerpasukan + (0.05) ZICT.

Jadual 8

Analisis Regresi Pelbagai (Stepwise) bagi Meramal Petunjuk Kemahiran Generik terhadap Kemahiran Komunikasi

\begin{tabular}{lccrccc}
\hline Model & $\mathrm{B}$ & Beta $(\beta)$ & \multicolumn{1}{c}{$\mathrm{T}$} & Sig. & $\mathrm{R}^{2}$ & Sumbangan (\%) \\
\hline (Tetap) & 0.47 & & 5.32 & 0.01 & & \\
Kepimpinan & 0.34 & 0.32 & 11.05 & 0.01 & .45 & 45 \\
Globalisasi & 0.16 & 0.22 & 9.25 & 0.01 & .08 & 7.7 \\
Kerohanian & 0.16 & 0.21 & 9.50 & 0.01 & .04 & 3.8 \\
BKritikalMM & 0.09 & 0.09 & 3.11 & 0.01 & .01 & 0.7 \\
KBerpasukan & 0.07 & 0.07 & 2.29 & 0.01 & .02 & 0.2 \\
ICT & 0.04 & 0.05 & 2.00 & 0.01 & .01 & 0.1 \\
\hline
\end{tabular}

Pemboleh ubah Bersandar : Komunikasi

Jadual 9 adalah nilai-t menunjukkan kesan pemboleh ubah-pemboleh ubah peramal dalam kombinasi linear yang tidak signifikan terhadap pemboleh ubah kriterion kemahiran komunikasi, yang menyebabkan pemboleh ubah-pemboleh ubah peramal tersebut iaitu TSosial, Alam Sekitar, EtikaMP, PSHayat, Keusahawanan, dan Pengurusan, tidak dapat di masukkan ke dalam model regresi. 
Jadual 9

Excluded Variable

\begin{tabular}{lrrrcc}
\hline \multirow{2}{*}{ Model } & & & & & Collinearity \\
& Beta in & $\mathrm{t}$ & Sig. & $\begin{array}{c}\text { Partial } \\
\text { Correlation }\end{array}$ & \begin{tabular}{c} 
Statistics \\
\cline { 5 - 6 }
\end{tabular} \\
TSosial & 0.03 & 1.54 & .13 & .043 & .70 \\
Alam Sekitar & 0.04 & 1.60 & .11 & .045 & .70 \\
Etika MP & 0.02 & .68 & .50 & .019 & .55 \\
PSHayat & -0.04 & -1.34 & .18 & -.038 & .34 \\
Keusahawanan & -0.02 & -.77 & .44 & -.022 & .39 \\
Pengurusan & 0.04 & 1.55 & .12 & .044 & .41 \\
\hline
\end{tabular}

Pemboleh ubah Bersandar : Komunikasi

\section{Pengaruh Kemahiran Generik kepada Kemahiran Berfikiran Kritikal dan Menyelesaikan Masalah}

Jadual 10 menunjukkan 7 pemboleh ubah peramal daripada 12 jumlah keseluruhan pemboleh ubah dalam kemahiran generik bagi pemboleh ubah kriterion BKritikalMM iaitu (1) PSHayat, (2) KBerpasukan, (3) Globalisasi, (4) Pengurusan, (5) ICT, (6) Komunikasi, dan (7) Kepimpinan yang di masukkan ke dalam model regresi pada aras $\mathrm{p} \leq .05$. Keadaan ini menunjukkan petunjuk utama peningkatan kemahiran berfikiran kritikal dan menyelesaikan masalah ialah kemahiran pembelajaran sepanjang hayat.

Jadual 10

Variable Entered/Removed (a)

\begin{tabular}{|c|c|c|c|}
\hline Model & $\begin{array}{l}\text { Variable } \\
\text { Entered }\end{array}$ & $\begin{array}{l}\text { Variables } \\
\text { Removed }\end{array}$ & Method \\
\hline 1. & PSHayat & - & $\begin{array}{l}\text { Stepwise (Criteria: Probalility-of-F-to- } \\
\text { enter } \leq .05 \text {, Probability-of-F-to-remove } \\
\geq .10)\end{array}$ \\
\hline 2. & KBerpasukan & - & $\begin{array}{l}\text { Stepwise (Criteria: Probalility-of-F-to- } \\
\text { enter } \leq .05 \text {, Probability-of-F-to-remove } \\
\geq .10)\end{array}$ \\
\hline 3. & Globalisasi & - & $\begin{array}{l}\text { Stepwise (Criteria: Probalility-of-F-to- } \\
\text { enter } \leq .05 \text {, Probability-of-F-to-remove } \\
\geq .10)\end{array}$ \\
\hline 4. & Pengurusan & - & $\begin{array}{l}\text { Stepwise (Criteria: Probalility-of-F-to- } \\
\text { enter } \leq .05 \text {, Probability-of-F-to-remove } \\
\geq .10 \text { ) }\end{array}$ \\
\hline
\end{tabular}

(sambungan) 


\begin{tabular}{|c|c|c|c|}
\hline Model & $\begin{array}{l}\text { Variable } \\
\text { Entered }\end{array}$ & $\begin{array}{l}\text { Variables } \\
\text { Removed }\end{array}$ & Method \\
\hline 5. & ICT & - & $\begin{array}{l}\text { Stepwise (Criteria: Probalility-of-F-to- } \\
\text { enter } \leq .05 \text {, Probability-of-F-to-remove } \\
\geq .10)\end{array}$ \\
\hline 6. & Komunikasi & - & $\begin{array}{l}\text { Stepwise (Criteria: Probalility-of-F-to- } \\
\text { enter } \leq .05 \text {, Probability-of-F-to-remove } \\
\geq .10)\end{array}$ \\
\hline 7. & Kepimpinan & - & $\begin{array}{l}\text { Stepwise (Criteria: Probalility-of-F-to- } \\
\text { enter } \leq .05 \text {, Probability-of-F-to-remove } \\
\geq .10 \text { ) }\end{array}$ \\
\hline
\end{tabular}

a. Pemboleh ubah Bersandar : BKritikalMM

Jadual 11 menunjukkan kolerasi antara pemboleh ubah kriterion dan pemboleh ubah peramal PSHayat ialah .71, korelasi antara pemboleh ubah kriterion dan kombinasi antara PSHayat dan KBerpasukan ialah .76. Manakala korelasi pemboleh ubah kriterion dan kombinasi linear antara ketujuh-tujuh pemboleh ubah peramal PSHayat, KBerpasukan, Globalisasi, Pengurusan, ICT, Komunikasi dan Kepimpinan ialah .79. Nilai $\mathrm{R}^{2}$ sebanyak .51 menunjukkan bahawa $51 \%$ perubahan dalam pemboleh ubah kriterion BKritikal adalah disebabkan oleh perubahan yang disebabkan oleh perubahan dalam PSHayat. Kombinasi PSHayat dan KBerpasukan menyumbangkan sebanyak 7\% (.58-.51) \% iaitu 6.8\% perubahan tambahan dalam BKrtikalMM. Manakala Globalisasi, Pengurusan, ICT, Komunikasi dan Kepimpinan masing-masing menyumbang sebanyak $2.4 \%, 0.8 \%, 0.8 \%, 0.5 \%$ dan $0.1 \%$ varians dalam BKritikalMM. Manakala kombinasi linear ketujuh-tujuh pemboleh ubah peramal tersebut menyumbang sebanyak $62 \%$ varians dalam pemboleh ubah kriterion BKritikalMM.

Jadual 11

Ringkasan Model Regresi Kemahiran BKritikalMM

\begin{tabular}{lcccc}
\hline Model & $\mathrm{R}$ & $\mathrm{R}^{2}$ & Adjusted R & Anggaran Ralat Piawai \\
\hline 1. & $0.71(\mathrm{a})$ & 0.51 & 0.51 & 0.40 \\
2. & $0.76(\mathrm{~b})$ & 0.58 & 0.58 & 0.37 \\
3. & $0.77(\mathrm{c})$ & 0.60 & 0.60 & 0.36 \\
4. & $0.78(\mathrm{~d})$ & 0.61 & 0.61 & 0.36 \\
5. & $0.79(\mathrm{e})$ & 0.62 & 0.61 & 0.35 \\
6. & $0.79(\mathrm{f})$ & 0.62 & 0.62 & 0.35 \\
7. & $0.79(\mathrm{~g})$ & 0.62 & 0.62 & 0.35 \\
\hline
\end{tabular}

(sambungan) 

a. Peramal (tetap) : PSHayat.
b. Peramal (tetap) : PSHayat, KBerpasukan.
c. Peramal (tetap) : PSHayat, KBerpasukan, Globalisasi.
d. Peramal (tetap) : PSHayat, KBerpasukan, Globalisasi, Pengurusan.
e. $\quad$ Peramal (tetap) : PSHayat, KBerpasukan, Globalisasi, Pengurusan, ICT.
f. Peramal (tetap) : PSHayat, KBerpasukan, Globalisasi, Pengurusan, ICT, Komunikasi.
g. Peramal (tetap) : PSHayat, KBerpasukan, Globalisasi, Pengurusan, ICT, Komunikasi, Kepimpinan.
h. Pemboleh ubah Bersandar : BKritikalMM.

Jadual 12 pada model 7 adalah keputusan nilai-F $(7,1254)=$ $295.26, \mathrm{p}<.05)$ menunjukkan bahawa terdapat perhubungan antara ketujuh-tujuh pemboleh ubah peramal tersebut dengan pemboleh ubah kriterion pada atas signifikan $\mathrm{p}<.05$. Nilai ini menunjukkan $58 \%$ sumbangan tujuh konstruk tersebut (PSHayat, KBerpasukan, Globalisasi, Pengurusan, ICT, Komunikasi dan Kepimpinan) terhadap varians kemahiran BKritikalMM adalah signifikan.

\section{Jadual 12}

\section{Analisis Varians Kemahiran BKritikalMM}

\begin{tabular}{clrrrrr}
\hline Model & & $\begin{array}{c}\text { Sum of } \\
\text { Squares }\end{array}$ & df & $\begin{array}{r}\text { Mean } \\
\text { Square }\end{array}$ & F & Sig \\
\hline 1. & Regression & 204.98 & 1 & 204.98 & 1298.96 & $0.01(\mathrm{a})$ \\
& Residual & 198.83 & 1260 & 0.16 & & \\
& Total & 403.82 & 1261 & & & \\
2. & Regression & 232.41 & 2 & 116.21 & 853.55 & $0.01(\mathrm{~b})$ \\
& Residual & 171.41 & 1259 & 0.14 & & \\
& Total & 403.82 & 1261 & & & \\
3. & Regression & 242.16 & 3 & 80.72 & 628.14 & $0.01(\mathrm{c})$ \\
& Residual & 161.66 & 1258 & 0.13 & & \\
& Total & 403.82 & 1261 & & & \\
4. & Regression & 245.67 & 4 & 61.42 & 488.18 & $0.01(\mathrm{~d})$ \\
& Residual & 158.14 & 1257 & 0.13 & & \\
& Total & 403.82 & 1261 & & & \\
5. & Regression & 248.57 & 5 & 49.71 & 402.21 & $0.01(\mathrm{e})$ \\
& Residual & 155.24 & 1256 & 0.12 & & \\
& Total & 403.82 & 1261 & & & \\
6. & Regression & 250.67 & 6 & 41.78 & 342.37 & $0.01(\mathrm{f})$ \\
& Residual & 153.14 & 1255 & 0.12 & & \\
& Total & 403.82 & 1261 & & & \\
7 & Regression & 251.33 & 7 & 35.90 & 295.26 & $0.01(\mathrm{~g})$ \\
& Residual & 152.49 & 1254 & 0.12 & & \\
& Total & 403.82 & 1261 & & & \\
\hline
\end{tabular}

(sambungan) 

a. Peramal (tetap) : PSHayat.
b. Peramal (tetap) : PSHayat, KBerpasukan.
c. Peramal (tetap) : PSHayat, KBerpasukan, Globalisasi.
d. Peramal (tetap) : PSHayat, KBerpasukan, Globalisasi, Pengurusan.
e. Peramal (tetap) : PSHayat, KBerpasukan, Globalisasi, Pengurusan, ICT.
f. Peramal (tetap) : PSHayat, KBerpasukan, Globalisasi, Pengurusan, ICT, Komunikasi.
g. Peramal (tetap) : PSHayat, KBerpasukan, Globalisasi, Pengurusan, ICT, Komunikasi, Kepimpinan.
h. Pemboleh ubah Bersandar : BKritikalMM.

Jadual 13 menunjukkan nilai pekali regresi $b$ bagi keenamenam pemboleh ubah peramal dalam bentuk kombinasi linear. Nilai $\beta$ mewakili pekali regresi piawai bagi ketujuh-tujuh pemboleh ubah peramal tersebut dalam bentuk kombinasi linear. Manakala nilai-t menunjukkan keputusan yang signifikan pada $\mathrm{p}<.05$. Dengan itu, multiple linear regression adalah:

ZBKritikalMM $=(0.27)$ ZPSHayat $+(0.20)$ ZKBerpasukan + $(0.12)$ ZGlobalisasi $+(0.12)$ ZPengurusan $+(0.10)$ ZICT $+(0.08)$ ZKomunikasi + (0.07) ZKepimpinan.

Jadual 13

Analisis Multi-Regresi (Stepwise) bagi Meramal Kontribusi Konstruk GeSIHE terhadap Kemahiran BKrtikalMM

\begin{tabular}{lcccccc}
\hline \multicolumn{1}{c}{ Model } & $\mathrm{B}$ & Beta $(\beta)$ & $\mathrm{T}$ & Sig. & $\mathrm{R}^{2}$ & Sumbangan $(\%)$ \\
\hline (Tetap) & 0.24 & & 2.57 & .01 & & \\
PSHayat & 0.28 & 0.27 & 9.18 & .00 & .51 & 50.8 \\
KBerpasukan & 0.22 & 0.20 & 7.31 & .00 & .07 & 6.8 \\
Globalisasi & 0.09 & 0.12 & 5.07 & .00 & .02 & 2.4 \\
Pengurusan & 0.07 & 0.12 & 4.20 & .00 & .01 & 0.8 \\
ICT & 0.10 & 0.10 & 4.57 & .00 & .01 & 0.8 \\
Komunikasi & 0.08 & 0.08 & 3.11 & .00 & .01 & 0.5 \\
Kepimpinan & 0.07 & 0.07 & 2.32 & .02 & .01 & 0.1 \\
\hline
\end{tabular}

Pemboleh ubah Bersandar : BKritikalMM

Nilai-t dalam Jadual 14 menunjukkan kesan pemboleh ubahpemboleh ubah peramal dalam kombinasi linear yang tidak signifikan terhadap pemboleh ubah kriterion kemahiran BKritikalMM, yang menyebabkan pemboleh ubah-pemboleh ubah peramal tersebut iaitu TSosial, Alam Sekitar, EtikaMP, Kerohanian, dan Keusahawanan tidak dapat di masukkan ke dalam model regresi. 
Jadual 14

Excluded Variable

\begin{tabular}{lccccc}
\hline \multicolumn{1}{c}{ Model } & Beta in & $\mathrm{t}$ & Sig. & $\begin{array}{c}\text { Partial } \\
\text { Correlation }\end{array}$ & $\begin{array}{c}\text { Collinearity } \\
\text { Statistics }\end{array}$ \\
\cline { 6 - 6 } TSosial & -0.00 & -0.16 & 0.87 & -0.01 & 0.75 \\
Alam Sekitar & -0.01 & -0.39 & 0.70 & -0.01 & 0.74 \\
EtikaMP & 0.00 & 0.03 & 0.98 & 0.00 & 0.64 \\
Kerohanian & -0.01 & -0.36 & 0.72 & -0.01 & 0.61 \\
Keusahawanan & 0.07 & 1.94 & 0.05 & 0.06 & 0.26 \\
\hline
\end{tabular}

Pemboleh ubah Bersandar : BKritikalMM

\section{PERBINCANGAN DAN IMPLIKASI KAJIAN}

Kemahiran Komunikasi dan BKritikalMM merupakan kemahiran yang diterapkan dalam semua subjek disiplin pengajian akademik di IPT (Anuwar Ali, 2006). Kemahiran BKritikalMM telah dipilih sebagai faktor kriterion kerana kemahiran ini digunakan dalam sesuatu pengajaran dan pembelajaran bermula di sekolah lagi (Kamarudin, 2003). Mahasiswa yang bakal menjadi pemimpin haruslah dipupuk untuk berfikir secara kritis dan rasional supaya pembentukan masyarakat madani berasaskan intelektual dapat dihasilkan. Kurikulum Pendidikan KBSM, dalam mata pelajaran tertentu telah digubal bagi penyepaduan kemahiran generik yang diperlukan oleh seseorang pelajar dalam melengkapkan diri sebagai tenaga kerja dalam industri (Pusat Perkembangan Kurikulum, 2001a). Oleh itu, sistem pendidikan persekolahan di Malaysia, telah menggariskan kemahiran generik seperti kemahiran berkomunikasi, kemahiran menggunakan teknologi, kemahiran merancang dan mengelola aktiviti, kemahiran bekerja dengan orang lain dan dalam kumpulan, kemahiran menyelesaikan masalah, kemahiran mengurus, memilih dan menganalisa maklumat, kemahiran menggunakan idea dan teknik matematik, dan kemahiran memahami budaya diperlukan oleh pelajar sebagai persediaan untuk kerjaya (Pusat Perkembangan Kurikulum, 2001b).

Kajian ini selari dengan kajian di Australia oleh Hambur, Rowe dan Luc (2002) kesemua universiti di Australia telah memilih kemahiran pemikiran kritikal, penyelesaian masalah dan komunikasi (interpersonal dan penulisan) sebagai asas kepada 
kemahiran-kemahiran yang lain dan merupakan kemahiran boleh pindah (transferable) serta mudah diukur. Kajian yang dijalankan di Amerika, Britain dan Kanada juga telah mendapati usaha memperluas dan memperbaiki aspek pedagogi dan pentaksiran pemikiran kritikal telah menjadi satu perkara yang perlu dan mesti dalam sistem pendidikan (Morgan, 1995; Tucker, 1996). Kemahiran ini juga menjadi fokus penting bagi universiti, agensi kerajaan dan majikan di negara-negara lain (Hambur, Rowe \& Luc, 2002). Kajian ini juga selari dengan dapatan kajian oleh Quek (2005), yang mendapati kemahiran interpersonal dan kemahiran kognitif adalah antara kemahiran penting yang diperlukan untuk keberkesanan dalam pekerjaan.

Mengintergrasikan kemahiran BKritikalMM dengan kemahiran Komunikasi adalah satu langkah yang bijak kerana kedua-dua kemahiran ini amat diperlukan untuk melahirkan pelajar yang berkualiti dan pandai berhujah. Korelasi komunikasi dengan pemikiran manusia sangat rapat kerana kebolehan seseorang itu berinteraksi secara bebas memperlihatkan kekuatan minda mereka menjana pemikiran yang bermutu. Setiap butir pemikiran yang dilahirkan dan dipamerkan terlebih dahulu distruktur, disusun, dipilih, disunting, dikemas kini, ditapis dalam minda sebelum dilahirkan melalui saluran komunikasi. Pemikiran yang baik tidak dapat dilahirkan tanpa kecekapan berkomunikasi, dan keupayaan berkomunikasi yang baik pula tidak mungkin dapat dilakukan sekiranya ada permasalahan dalam berfikir. Kajian ini disokong oleh pakar-pakar pendidikan (Golman \& Hasselbring, 1997; Montague, Wagner \& Morgan, 2000) yang menegaskan bahawa keperluan untuk mempersiapkan diri bagi masyarakat secara amnya, dan pelajar-pelajar khususnya memerlukan kemahiran penyelesaian masalah, kemahiran komunikasi, kemahiran membuat keputusan dan sebagainya.

Dapatan analisis data bagi faktor petunjuk atau penyumbang kepada kemahiran komunikasi menunjukkan bahawa enam pemboleh ubah peramal iaitu Kepimpinan, Globalisasi, Kerohanian, BKritikalMM, KBerpasukan, dan ICT merupakan peramal bagi skor indeks Komunikasi. Walau bagaimanapun, keputusan kajian menolak andaian pengkaji bahawa TSosial, Alam Sekitar, EtikaMP, PSHayat, Keusahawanan, dan Pengurusan merupakan peramal bagi Kemahiran Komunikasi pelajar UKM.

Secara signifikan, skor Kepimpinan menyumbangkan sebanyak $45 \%$ varians dalam skor Kemahiran Komunikasi. Hal ini bererti Kepimpinan atau keupayaan memimpin, menghasilkan 
idea dan sering berinteraksi dalam masa yang singkat merupakan petunjuk utama yang menyebabkan pelajar universiti tersebut mahir dalam komunikasinya. Kemahiran kepimpinan merupakan faktor pengaruh atau penyumbang utama kepada kemahiran komunikasi. Dapatan ini selari dengan Day (2001); Day dan Halpin (2004); Huber (2004); Van Knippenberg dan Hogg (2003); Yukl (2006) yang menyatakan kemahiran kepimpinan merupakan kompetensi yang diperlukan di pelbagai organisasi. Seorang pemimipin yang baik adalah mereka yang boleh berkomunikasi dengan baik dan lancar. Kemahiran berkomunikasi dengan baik akan membantu seseorang pemimpin menyampaikan hasrat dan buah fikirannya kepada orang yang dipimpinnya dengan berkesan. Menurut Chomsky (1957), proses komunikasi berlaku apabila adanya penutur dan pendengar. Setiap penutur dan pendengar harus memiliki dua perkara penting iaitu kompetensi atau kemahiran dan performance. Dapatan kajian ini menyokong kajian yang telah dijalankan oleh Siti Rahayah et al., (2008a) yang menyatakan kemahiran komunikasi, kepimpinan dan kerja berpasukan adalah tiga kemahiran yang menjadi asas dan sangat penting bagi perkembangan kemahiran generik pelajar prasiswazah di UKM.

Dapatan kajian ini juga selari dengan kajian yang dijalankan oleh Borthwick dan Wissler (2003) di 34 buah universiti di Australia. Dapatan kajian menunjukkan sebanyak 28 universiti daripada 34 universiti di Australia telah memilih bahawa kemahiran komunikasi dan kepimpinan merupakan dua kemahiran generik yang paling penting dan diterapkan dalam pendidikan. Dapatan ini memperkukuhkan lagi kajian oleh Siti Rahayah et al. (2008a) yang menyatakan kemahiran komunikasi, kepimpinan, dan kerja berpasukan adalah merupakan kemahiran asas dan diterapkan dalam disiplin subjek pengajaran dan pembelajaran bagi pelajar prasiswazah di UKM. Keadaan ini juga bersesuaian dengan apa yang dinyatakan oleh Crosbie (2005); Reynolds (2005), pemimpin yang berjaya memerlukan kemahiran berkomunikasi seperti kemahiran menulis, berinteraksi dan lain-lain bentuk komunikasi. Manakala 20 peratus kejayaan seorang pemimpin dibantu oleh kemahiran komunikasi yang berkesan dalam aspek berkongsi maklumat dengan rakan, ketua, dan penulisan kertas (menjawab surat, menulis surat, dan menulis laporan) yang berkaitan dengan tugas yang dilakukan.

Dapatan ini juga menyokong kajian oleh Abel (2002); Gutteridge (2004); Muir (2004); Somerser (2001), yang berpendapat seorang pemimpin harus menguasai kemahiran komunikasi yang berkesan dan boleh berunding bagi mencapai matlamat dalam 
perbincangan yang dijalankan. Pelajar perlu diterapkan dengan kemahiran komunikasi dan kepimpinan kerana melalui kemahiran ini pelajar akan lebih memahami apa yang diperlukan oleh seseorang dan bagaimana untuk mempengaruhi dan membimbing orang lain bagi mencapai matlamat yang dirancangkan.

Dapatan analisis data bagi faktor petunjuk atau penyumbang kepada kemahiran BKritikalMM menunjukkan bahawa tujuh pemboleh ubah peramal iaitu PSHayat, KBerpasukan, Globalisasi, Pengurusan, ICT, Komunikasi dan Kepimpinan merupakan peramal bagi skor indeks BKritikalMM. Walau bagaimanapun, keputusan kajian menolak andaian pengkaji bahawa TSosial, Alam Sekitar, EtikaMP, Kerohanian, dan Keusahawanan merupakan peramal bagi Kemahiran BKritikalMM pelajar UKM.

Secara signifikan, skor PSHayat menyumbangkan sebanyak $50.8 \%$ varians dalam skor Kemahiran BKritikalMM. Hal ini bererti PSHayat atau keupayaan pembelajaran sepanjang masa dan menghasilkan idea dalam masa yang singkat merupakan petunjuk utama yang menyebabkan pelajar universiti tersebut mahir dalam BKritikalMM. Kajian ini selari dengan kajian yang dijalankan oleh Chaffee (1991) bahawa proses belajar dan berfikir adalah suatu proses yang saling berkait sepanjang hayat. Maka adalah lebih mudah menerima pembelajaran dalam kumpulan dan menggunakan otak untuk berfikir serta menyelesaikan sesuatu masalah. Berdasarkan cara ini, maka pelajar akan mendapat ilmu yang dipelajarinya (Dodridge, 1999).

Dapatan kajian ini selari dengan kajian Hayward dan Fernandez (2004); Higgins, Hall, Baumfielda dan Moseley (2005) yang menyatakan kemahiran pemikiran kritikal merupakan kemahiran yang sering digunakan sepanjang masa dan ketika semasa pelajar mengumpulkan maklumat dan bahan bagi melaksanakan tugasan sepanjang masa pengajian pelajar di institusi pengajian. Pelajar sering berdepan dengan pelbagai maklumat dan isu yang boleh didapati dengan mudah, oleh itu kemahiran pemikiran kritikal membolehkan pelajar menapis dan menyaring maklumat yang berkualiti dan berwasit bagi menghasilkan tugasan dan hasil penyelidikan yang berkualiti.

Dapatan kajian ini menunjukkan bahawa empat kemahiran yang diukur dalam kemahiran generik iaitu (1) tanggungjawab sosial, (2) menghargai alam sekitar, (3) etika, moral dan profesionalisme dan (4) keusahawanan adalah kemahiran bukan petunjuk utama atau bukan pengaruh utama kepada peningkatan kompetensi generik dalam kemahiran komunikasi dan berfikiran kritikal dan menyelesaikan masalah. Dapatan ini bertentangan 
dengan kajian yang dijalankan oleh Goldfinch dan Hughes (2007); Haris (2006) yang menyatakan kemahiran etika, sosial, persekitaran dan keusahawan adalah faktor yang mempengaruhi peningkatan dan keberkesanan dalam kemahiran generik pelajar-pelajar prasiswazah di institusi pengajian tinggi. Namun, keempat-empat kemahiran ini bukan tidak penting dalan sistem pendidikan di malaysia tetapi akan dijadikan sebagai kemahiran sampingan bagi meningkatkan kemahiran generik pelajar-pelajar secara keseluruhan. Sehubungan itu, pelajar yang akan menamatkan pengajian daripada universiti atau institusi pengajian tinggi di harapkan telah dapat menguasai kemahiran yang utama dan sampingan bagi mengharungi dunia pekerjaan dan kehidupan dengan lebih bersedia dan cemerlang.

\section{KESIMPULAN}

Kesimpulannya, kajian ini penting sebagai input kepada UKM dan institusi pengajian yang lain kerana dapat memberi isyarat tentang kemahiran-kemahiran yang memberi sumbangan atau menjadi petunjuk yang tinggi kepada kompetensi generik. Tenaga pengajar akan dapat memberi penekanan pada kemahiran yang memberi sumbangan yang besar pada kemahiran generik seperti Kemahiran Komunikasi, Berfikiran Kritikal dan Menyelesaikan Masalah, Kepimpinan, dan Pembelajaran Sepanjang Hayat serta mengintegrasikan atau menggabungjalinkan kemahiran-kemahiran tersebut dalam pengajaran dan pembelajaran.

Tenaga pengajar juga perlu lebih berhati-hati terhadap potensi dan keperluan pelajar berkaitan dengan kemahiran yang diperlukan bagi meningkatkan pencapaian akademik dan kemahiran generik pelajar. Kemahiran generik utama seperti komunikasi dan berfikiran kritikal dan menyelesaikan masalah merupakan kemahiran yang mempunyai hubungan kuat dengan pencapaian akademik pelajar. Maka, perancangan yang rapi dan sistematik perlu dilakukan oleh pihak yang terlibat bagi memastikan kemahiran-kemahiran generik diterapkan dan diintegrasikan dalam pengajaran dan pembelajaran di sepanjang pengajian pelajar di universiti.

Pendedahan perlu diberikan kepada semua pelajar berkaitan kemahiran generik mengikut kerangka kelayakan yang telah ditetapkan dalam MQF 2006 bagi melayakkan pelajar berdasarkan standard Lembaga Akredetasi Malaysia (LAN). Pentaksiran kemahiran generik ini adalah perkara yang wajib dilaksanakan oleh pihak universiti dan institusi pengajian tinggi semasa kemasukan pelajar ke universiti. 


\section{RUJUKAN}

Abell, A. (2002). Softly approach. Information World Review, 186, 56-58.

ACT, Inc. (2000). Workplace essential skills: Resources related to the scans competencies and foundation skills. Iowa City, IA: ACT Publications. (INT)

Altman, I., \& Taylor, D.A. (1973). Social penetration: The development of interpersonal relationship. Holt, Rinehart \& Winston: New York.

Allan, J., \& Clarke, K. (2007). Nurturing supportive learning environments in higher education through the teaching of study skills: To embed or not to embed? International Journal of Teaching and Learning in Higher Education, 19 (1), 64-76.

Anuwar Ali. (2006, December). Revamping the Malaysian education system. Paper presented at The National Economics Conference, Hilton Hotel, Kuala Lumpur.

Ballantine, J., \& Larres, M. P. (2007). Cooperative learning: A pedagogy to improve students' generic skills? Journal Education and Training, 49 (2), 126-137.

Bennis, W. (1995, April). Critical thinking. Executive Excellence, 7. Berger. (1985). Review of Watson-Glaser critical thinking appraisal. In J.V. Mitchell (Ed.), Ninth mental measurement yearbook (pp. 1692-93). Lincoln, NE: Buros Institute of Mental Measurement of the University of Nebraska.

Berscheid, E. (1994). Interpersonal relationships. Annual Review of Psychology, 45, 79-129.

Biggs, J. (2003). Teaching for quality learning at university. Maidenhead: Society for Research into Higher Education \& Open University Press.

Bjorkland, D.F,. \& Pellegrini, A. D. (2000). Child development and evolutionary psychology. Child Development, 71, 1687-1908.

Bloom, B. S. (Ed.), (1956). Taxonomy of educational objectives. Volume 1: Cognitive Domain. New York: McKay.

Bond, T.G., \& Fox, C. M. (2001). Applying the rasch model: Fundamental measurement in the human sciences. New Jersey: Lawrence Erlbaum Associates Publishers, London.

Bond, T.G., \& Fox, C. M. (2007). Applying the rasch model: Fundamental measurement in the human sciences. Second Edition. New Jersey: Lawrence Erlbaum Associates Publishers, London. 
Boud, D., \& Middleton, H. (2003). Learning from others at work: Communities of practice and informal learning. Journal of Workplace Learning: Employee Counselling Today, 15 (5), 194-202.

Browne, M. N., \& Keeley, S. M. (2000). Asking the right questions: A guide to critical thinking (6th ed.). Upper Saddle River, NJ: Prentice Hall.

Borthwick, J., \& Wissler, R. (2003). Postgraduate research students and generic capabilities: Online directions. Canberra: Commonwealth Department of Education, Science and Training.

Chaffee, J. (1991). Thinking critically (3red.). Boston: Houghton Mifflin Company.

Churchman. (1971). The design of inquiring system. Basic Books Inc.

Chomsky. (1957). Syntactic structures. The Hague: Mouton. (First work on Transformational Grammer.

Conrad, C., \& Poole, M. S. (2002). Strategic organizational communication in a global economy (5th ed.). New York: Harcourt.

Creswell, J. W. (2008). Education research: Planning, conducting, and evaluating quantitative and qualitative research: Third Edition. Pearson International Edition.

Crosbie, R. (2005). Learning the soft skills of leadership. Industrial and Commercial Training, 37 (1), 45-51.

Day, D. (2001). Leadership development: A review in context. Leadership Quaterly, 11, 581-613.

Day, D., \& Halpin, S. (2004). Growing leaders for tomorrow: An introduction. In Day, D., Zaccaro, S., \& Haqlpin, S. (Eds), Leader development for transforming organizations: growing leaders for tomorrow. Eribaum, Mahwah (3pp-22. New Jersey.

Dekkhoff, G. (1992). Statistic for the social and behavioral sciences. Dubuque: Wm. C. Brown Publishers.

Dench, S. (1997) 'Changing skill needs: what makes people employable?' Industrial and Commercial Training, 29 (6), 190-193.

Dewey, J., (1933). How we think: A restatement of the relation of reflective thinking to the educational process. Lexington, MA: Heath.

Dodridge, M. (1999). Learning outcomes and their assessment in higher education. Engineering Science and Education Journal, 8 (4), 161-168. 
Dunne, E., Bennett, N \& Carre, C. (2000). Skill development in higher education and employment. Bristol.

Eisenberg, E. M., \& Goodall, H. L. (2004). Organizational communication: Balancing creativity and constraint (4th ed.). New York: Bedford/St. Martin's.

Ennis, R. H. (1996). Critical thinking. Upper Saddle River, NJ: Prentice-Hall.

Ennis, R. H. (2000). Test reliability: A practical exemplification of ordinary language philosophy. Philosophy of Education Society. Kappa Phi Journal, 65(1), 28-31.

Eunson, B. (2007). Communication in the workplace. First Published. Australia: John Wiley \& Sons.

Falk, I., \& Millar, P. (2002). Implications of 'non-standard work practices' for literacy and numeracy. ALNARC National Research Program Commonwealth of Australia.

Fisher, A., Scriven, M. (1997). Critical thinking: Its definition and assessment. Point Reyes, CA: Edgepress.

Fiske, J. (1990). Introduction to communication studies (2nd ed). London: Routledge.

Fox, C.M., \& Jones, J.A. (1998). Uses of rasch modeling in counseling psychology research. Journal of Counseling Psychology, 45(1), 30-45.

Gardner, C. T., Milne, M. J., Stringer, C. P. \& Whiting, R. H. (2005). Oral and written communication apprehension in accounting students: Curriculum Impacts and Impacts on Academic Performance. Accounting Education, 14 (3), 313-36.

Gay, L.R., \& Airasian, P. (2003). Educational research (7th ed.). Upper Saddle River, NJ: Merrill.

Goldstein, F. C., \& Levin, H. S. (1987). Disorders of reasoning and problem-solving abilities. In A. L. Benton, M. R. Meier, \& L. Diller (Eds.), Neuropsychological rehabilitation (pp.327344). New York: Guilford Press.

Goldfinch, J., \& Hughes, M. (2007). Skills, learning styles and success of first-year undergraduates. Active Learning in Higher Education, 8, 259.

Golman, S. R., Hasselbring, T. S. (1997). Achieving meaningful mathematics literacy for students with learning disabilities. Journal of Learning Disabilities, 30 (2), 198-208.

Gutteridge, T. G. (2004). Career in not four letter word. MidAmerican Journal of Business, 19 (1), 5-16.

Hair, J. F., Anderson, R. E., Tatham, R.L., \& Black, W. C. (2006). Multivariate data analysis. Upper Saddle River, NJ: Prentice Hall. 
Hambur, S., Rowe, K., \& Luc, L. T. (2002). Graduate skills assessment. Australian Council For Educational Research. Commonwealth Department of Education Science \& Training.

Harris, P. G. (2006). Environmental perspectives and behavior in China: Synopsis and bibliography. Environment and Behavior, 38 (5).

Hayward, G., \& Fernandez, R. M. (2004). From core skills to key skills: fast forward or back to the future? Oxford Review of Education, 30 (1), 117-45.

Higgins, S., Hall, E., Baumfield V. \& Moseley, D. (2005). A Metaanalysis of the impact of the implementation of thinking skills approaches on pupils. Research Evidence in Education Library. London: EPPI-Centre, Social Science Research Unit, Institute of Education, University of London.

Huber, S. G. (2004). School leadership and leadership development: Adjusting leadership theories and development programs to values and the core purpose of school. Journal of Education Administration, 42 (6), 669-684.

Huitt, W. (2007). Stages of mastery. Educational psychology interactive. Valdosta, GA: Valdosta State University. Retrieved from http://chiron.valdosta.edu/whuitt/exptl/stgmstry. html.

Jacobsen, R. L. (1993). Shaking up the MBA. Chronicle of Higher Education.

Jager, K. D., \& Nassimbeni, M. (2005). Information literacy and quality assurance in South African higher education institutions. South African Journal of Libraries and Information Science, 55, 31-38.

Kamarudin Hj Husin. (2003). Kemahiran berfikir dan berkomunikasi. Subang Jaya: Kumpulan Budiman Sdn. Bhd.

Kanapathy, V. (2001). Building Malaysia's IT society. Raffles Review, 5 (1), 1-14.

Kearns, P .(2001). Review of research: Generic skills for the new economy. NCVER. Adelaide

Kementerian Pengajian Tinggi. (2006). Modul pembangunan kemahiran insaniah (soft skills) untuk institusi pengajian tinggi Malaysia. Universiti Putra Malaysia.

Kementerian Sumber Manusia \& Kementerian Pengajian Tinggi. (2005). Laporan Tahunan.

Kinnick, K. N., \& Parton, S. R. (2005). Workplace communication: What the apprentice teaches about communication skills. Business Communication Quarterly, 68, 429. 
Linacre, J. M. (2007). A user's guide to WINSTEPS Rasch-Model computer programs. Chicago: MESA Press.

Lizzio, A., \& Wilson, K. (2004). First-year students' perceptions of capability. Carfax Publishing.

Lowe, H. \& Cook, A. (2003). Mind the gap: Are students prepared for higher education? Journal of Further and Higher Education, 27(1), 53-76.

Lublin, J. (2003). Generic objectives and transferable skills: Centre for teaching and learning: Good Practice in teaching and learning. Engineering Science and Education Journal, 8 (4), 161-168.

Martinez, M. M. S. (2005). What does "success skills" mean across the country? Defining success skills for the $21^{\text {st }}$ century. California: Los Rios Community College District's Workplace Learning Resource Center.

Mason, J. C. (1992). Business schools: Striving to meet customer demand. Management Review, 81(9), 10-14.

Mertes, L. (1991). Thinking and writing. Middle School Journal, 22, 24-25. Retrieved from http://chiron.edu/whuitt/col/cogsys/ critthnk.html.

Morgan, W. R. (1995). Assessment of critical thinking strategies utilized by community college students (Unpublished doctoral disssertation). School of Education, Kansas State University.

Montague, M., Morgan, T.H., \&. Warger, C. (2000). Solve it! Strategy instruction to improve mathematical problem solving. Learning Disabilities Research \& Practice, 15 (2), 110-116.

Muir, C. (2004). Learning soft skills at work: An interview with Annalee Luhman. Business Communication Quarterly, 67 (1), 95-101.

Murphy, R. (2001). A Briefing on key skills in higher education. University of Nottingham.

NCVER (National Centre for Vocational Education Research). 2003. Fostering generic skills in VET programs and workplaces: At a glance. NCVER, Adelaide.

Nik Aziz Nik Pa. (2008). Isu-isu kritikal dalam pendidikan matematik. Universiti Malaya.

Norris, S. P,. \& Ennis, R. H. (1989). Evaluation critical thinking. California: Critical Thinking Press and Software, Pacific Grove.

Norris, S. P. (1992). Testing for the disposition to think critically. Informal Logic, 3, 157-164. 
O'Hair, D., Friedrich, G.W., \& Dixon, L. D. (2002). Strategic communication in business and the professions (4th ed.). New York: Houghton Mifflin.

Organ, T. 1965. The art of critical thinking. Boston: Houghton Mifflin.

Pallant, J. (2001). SPSS Survival Manual: A step by step guide to data analysis using SPSS for windows. Ver. 10. Illinois: Allen \& Unwin.

Paul, R., \& Elder, L. (2001). Critical thinking: Tool for taking charge of your learning and your life. New Jersey: Prentice Hall: Upper Saddler River.

Posfas (Prepared by the Expert Group on Future Skills Needs Secretariat). 2006. The changing nature of generic skills.

Pincus, J. D., \& DeBonis, J. N. (2004). Top dog: A different kind of book about becoming an excellent leader. New York: McGraw-Hill

Price. J. L. (1997). Handbook of organizational measurement. International Journal of Manpower, 18, (4/5/6), 305-558.

Pusat Perkembangan Kurikulum. (2001a). Belajar cara belajar. Kementerian Pelajaran Malaysia.

Pusat Perkembangan Kurikulum (2001b). Kurikulum bersepadu sekolah menengah huraian sukatan pelajaran geografi sekolah menengah (Tingkatan 1). Kementerian Pendidikan Malaysia.

Quek, A. H. (1996). World culture and values: A process perspective. Paper presented at the European Business Conference, BadenWurttemberg.

Quek, A. H. (2005). Learning for the workplace: A case study in graduate employees' generic competencies. Journal of Workplace Learning, 17(4), 231-242.

Reynolds, A. (2005). Best behavior. Supply Management, 10 (7), 35. Retrieved October 2, 2008 from Proquest database.

Richardson, D. (2003, November). The transition to degree level study. Higher Education Academy Resource pages: http:// www.heacademy.ac.uk/resources.asp? Process=full_record $\&$ section $=$ generic $\&$ id $=506$

Rodiah Idris, Siti Rahayah Ariffin, \& Noriah Mohd Ishak. (2008a). Pemeriksaan ciri-ciri psikometrik instrumen pentaksiran kemahiran generik menggunakan pendekatan model Rasch. Seminar Kebangsaan Jawatankuasa Penyelaras Pendidikan Guru (JPPG 2008). 
Rodiah Idris, Siti Rahayah Ariffin, \& Noriah Mohd Ishak. (2008b). Pemeriksaan differential itemfunctioning (DIF) instrumen pentaksiran kemahiran generik. Seminar Psikologi dan Pembangunan Manusia.

Rodiah Idris, Datin Siti Rahayah Ariffin \& Noriah Mohd Ishak. (2009a). Pemeriksaan model pengukuran dalam confirmatory Factor Analysis (CFA) Instrumen Kemahiran Generik. Prosiding Seminar Pendidikan Serantau Ke-4 2009. Klana Resort, Seremban, Negeri Sembilan.

Rodiah Idris, Siti Rahayah Ariffin \& Noriah Mohd Ishak. (2009b). Differential item functioning analysis of the Malaysian generic skills instrument. Conference of the International Journal of Arts \& Sciences, 1(18). Austria

Rodiah Idris, Siti Rahayah Ariffin \& Noriah Mohd Ishak.( 2009c).

Application of Rasch model in validating the construct of measurement for generic skills Instrument for Higher Education (GeSIHE). Conference of the Pacific Rim Objective Measurement Symposium PROMS 2009. Hong Kong.

Rosenbusch, K., \& Townsend, C. (2004). The Relationship of gender and organizational setting to transformational and transactional leadership skills of selected college student leaders. Journal of Leadership Education, 3 (3).

Rogers, E. M. (1995). Diffusion of innovation. New York: Free Press. In Johnson, S. E,. \& Graber, B. E., Enlisting the social sciences in decisions about dam removal. Bioscience, 52 (8).

Schroder, H. M. (1989). Managerial competences: The key to excellence. Kendall-Hunt, Dubuque, IA.

Sekaran, U. (2003). Research methods for business (4th ed.). Hoboken, NJ: John Wiley \& Sons.

Sharifah Hapsah Syed Hasan Shahabudin. (2006). Kerangka kelayakan Malaysia. Lembaga Akreditasi Negara.

Shockley-Zalabak, P. (2002). Fundamentals of organizational communication: Knowledge, sensitivity, skills, and values (5th ed.). Boston: Allyn \& Bacon.

Siti Rahayah Ariffin, Noriah Mohd Ishak, Abdul Ghafur Ahmad, Rodiah Idris, \& Nur' Ashiqin Najmuddin. (2008a). Communication, leadership, and teamwork skills as core competencies among higher education students. Proceeding ASAIHL International Conference, Bangkok, 149-158. 
Siti Rahayah Ariffin, Noriah Mohd Ishak, Riza Atiq O.K Rahmad, Abdul Ghafur Ahmad, Rodiah Idris, Nur' Ashiqin Najmuddin. (2008b). Assessing generic skills using rasch model approach: A method for construct validity and reliability. International Conference on Education (ICEI 2008).

Siti Rahayah Ariffin, Rodiah Idris \& Nur'Ashiqin Najmuddin. (2008c). Inovation using rasch model approach in measuring generic skills. International Conference on Education (ICEI 2008).

Siti Rahayah Ariffin, Noriah Mohd Ishak, Roseni Ariffin, Abdul Ghafur Ahmad \& Rodiah Idris. (2008d). Evaluation approaches and challenges using structural equation model (SEM). Proceeding International Conference on the Education of Learner Diversity (ICELD 2008), 427-440.

Siti Rahayah Ariffin, Rodiah Idris \& Noriah Mohd Ishak. (2008e). Profil kemahiran generik pelajar-pelajar institut pengajian tinggi: Kajian kes di Universiti Kebangsaan Malaysia (UKM). Seminar Kebangsaan Jawatankuasa Penyelaras Pendidikan Guru (JPPG 2008).

Somerser, F. (2001). The softer side of leadership. CMA Management, 75 (7), 12-23.

Trenholm, S. (1999). Thinking through communication: An introduction to the study of human communication (3rd ed.). Boston: Allyn and Bacon.

Trueman, M., \& Hartley, J. (1996). A Comparison between the time-management skills and academic performance of mature and traditional-entry university students. Higher Education 32(2), 199-215.

Tucker, R. W. (1996). Less than critical thinking. Assessment and Accountability Forum, 6 (numbers 3 and 4). In Goodman, W. (2008). Critical-thinking assessment: A case applying resampling to analyze the sensitivity of a hypothesis test to confounding. CS- BIGS 2(1), 9-20. Retrieved from http:// www.bentley.edu/csbigs/vol2-1/goodman.pdf.

Van Knippenberg, D., \& Hogg, M. A. (2003). A social identity model of leadership effectiveness in organizations. Journal Research in Organizational Behavior, 25, 243-295.

Wilhelm, W. J., Logan, J., Smith, S. M., Szul, L. F. (2002). Meeting the demand: Teaching soft skills, 43-57.

Wright, B., \& Stone, M. (1999). Measurement Essentials. (2nd ed.). Wilmingtone, Delaware: Wide Range, Inc. 
Wright, B. D., \& Masters, G. N. 1982. Rating scale analysis. Chicago: MESA Press.

Yukl, G. (2006). Leadership in organizations (6th ed.). Upper Saddle River, NJ: Prentice Hall.

Young, A., \& Perrewe, P. (2004). The role of expectations in the mentoring exchange: An analysis of mentor and protégé expectations in relations to perceived support. Journal of Managerial Issues, XVI, 103-126. 